\title{
Centenary of the Department of Geography, University of Aberdeen
}

Lorna J. Philip ${ }^{\mathrm{a}}$ and Kevin J. Edwards ${ }^{\mathrm{a}, \mathrm{b}}$

${ }^{a}$ Department of Geography and Environment, School of Geosciences, University of Aberdeen, Aberdeen, UK

${ }^{b}$ Scott Polar Research Institute, University of Cambridge, Cambridge, UK

Corresponding Author: Lorna Philip I.philip@abdn.ac.uk 


\title{
Centenary of the Department of Geography, University of Aberdeen
}

\begin{abstract}
Prior to the amalgamation of Aberdeen's two medieval universities in 1860, Geography had been taught to undergraduate students at both King's and Marischal Colleges since at least the late 16th Century. First mooted in the early 1900s, it was not until 1919 that a lectureship in Geography at Aberdeen was created and a 'Department of Geography' came into being. In this contribution we chronicle how, over a century, the Geography department has evolved, highlighting developments in the curriculum and research-related activities. The early decades of the Department were shaped by John McFarlane, the first and only full-time appointee in Geography until his retirement in 1945. The post-World War II period, led by Andrew O'Dell, saw Geography develop into a large and influential Department. During the 1960s and 1970s, the Department (and University) experienced unprecedented levels of growth. Student numbers, research output and income accelerated apace. In the recent past national assessments of research and teaching quality and institutional restructuring have prompted further change. As the Department enters a second century it remains committed to delivering a high quality education to undergraduate and postgraduate students and to the pursuit of excellent geographical research.
\end{abstract}

Keywords: Geography; University of Aberdeen 


\section{Thay haif said}

\section{Quhat say thay}

\section{Lat thame say}

(They have said, What say they? Let them say)

The quotation above, in Scots, is the motto of George Keith, Earl Marischal and the founder of Marischal College. Established in 1593, Marischal College was the second University in Aberdeen, joining King's College which had been founded by papal bull in 1495 , almost a century previously (Figures 1, 2, 3 and 4). The two institutions merged to form the University of Aberdeen in $1860^{i}$. Geography is known to have been taught to undergraduate students at Marischal College since 1593 and may have been in curricula taught at King's even earlier in the sixteenth century. This paper recounts a history of geographical education at the University of Aberdeen, teaching that has, since 1919, taken place within a department of Geography. Returning to the Earl Marischal's motto, what do archival and other sources tell us about geographical education at Marischal College, King's College and at the University of Aberdeen? What has been said or written about the people who have constructed and delivered geographical education and pursued geographical research and other scholarly activities? This paper, along with others within this Special Issue of the Scottish Geographical Journal, addresses such questions in a celebration of the contributions to geographical education and wider scholarship that have been made at Aberdeen.

The first section of this paper presents an overview of Geography as a university subject taught to successive cohorts of Aberdeen University students - an education formally recorded as having its origins in the late 1500s. The prelude to the formal 
establishment of a Department of Geography in 1919 commenced with the passing of the 1889 Universities (Scotland) Act, following which a major restructuring of tertiary education in Scotland occurred. Specifically, there was an expansion of the Master of Arts (MA)ii curriculum and the introduction of the Bachelor of Science (BSc) degrees which both led to teaching becoming structured around disciplines in which students could specialise at the Honours degree level. Academic departments, the precursors of the disciplinary units that form the backbone of the University today, albeit with much

smaller staff numbers, began to be organised in the wake of the 1889 Act. First mooted in the early years of the 1900s, it was not until 1919 that a lectureship in Geography at Aberdeen was created and a 'Department of Geography' came into being.

Section three is focused on the 1960s, a decade of unprecedented expansion in British Higher Education and Section four documents a period of further growth and financial crisis - the 1970s and 1980s. Section 5 reflects on the recent past, decades when external assessments of research quality, greatly increased student numbers and institutional restructuring and attendant challenges have been influential for Geography. The paper concludes with some reflections on future directions as Geography at Aberdeen enters its second century.

\section{University instruction in geography at Aberdeen before 1919}

Mathematical and philosophical principles of cosmology that prevailed in the sixteenth and seventeenth centuries viewed the whole earth as an entity located with a celestial sphere which could be described in terms of regional differences (chorography). Cosmology was taught in all five of the 'ancient' Scottish Universities iii and cosmological curricula based on Aristotelian and Ptolemaic principles were gradually 
superseded in the 1600 s and early 1700 s by teaching informed by the writings of Nicolous Copernicus and Tycho Brahe and then by exponents of the new scientific method such as René Descartes and Isaac Newton (Russell, 1974; Withers \& Mayhew, 2002).

\section{Geographical teaching at King's College and Marischal College}

Both King's and Marischal Colleges offered undergraduate programmes, taught over four years, that led to the award of the degree of Master of Arts (MA). Records from both King's and Marischal Colleges contain reference to undergraduates being taught ‘Geography' at various points from the late 1500s onwards. Shepherd's (1987) overview of the content of the fourteen known surviving manuscript student notebooks for King's College prepared between 1690 and 1720 identified two instances of Geography having been taught. William Black taught Geography and Cosmography in 1692 and Geography was taught by George Skene in 1702. The scrutiny of Aberdeen

archival material by Withers and Mayhew (2002) led to the compilation of a list of the Regents, and later Professors, known to have taught Geography at both Aberdeen Universities (see Table 1), the earliest teaching of Geography being ascribed to William Black of King's College in the teaching session of 1692-93. Other sources report that geography was a formal part of the arts curriculum followed at Marischal and King's Colleges for at least one hundred years before William Black's geography and cosmography lectures were delivered. For example, the Marischal College Foundation Charter of 1593 set out the contents of a liberal arts curriculum to be followed by undergraduate students. Greek and Latin dominated the first and second years, but the third year curriculum was to include 'arithmetic, geometry, Aristotle's ethics and 
politics (in Greek), Cicero's treatise On Duties (for its moral as well as its literary value) and some natural history, again from Aristotle, geography, history and astronomy, and on to Hebrew' (Carter \& McLaren, 1995, p. 23). Further, the foundation charter required the Principal of the College 'to expound Geography, History and the outlines of Astronomy' (Anderson 1889-98, I, p. 63, cited in Withers \& Mayhew, 2002, p. 21). Geography was also part of the curriculum at King's College during the second quarter of the seventeenth century. Curricula at King's and Marischal Colleges and at the Universities of St Andrews and Edinburgh were compared at a meeting held in 1648, a report of which led Withers \& Mayhew (2002) to "judge [that] ... geography was taught in each of these places in association with astronomy and the use of celestial and terrestrial globes' (p. 21).

Firm evidence that students at Marischal College were being taught geography in the 1630 s comes from a rare surviving set of student notes or dictates held in the Aberdeen University Library Special Collections. James Downie's (or Doun's) dictates were taken down in 1633-34 when he was a final year undergraduate student lectured to by William Johnston, the first Professor of Mathematics at Marischal. The dictates record that Johnston's lectures were on 'mathematics, chronology, cosmography (an account of the earth), hydrography (an account of the seas), trigonometry, geometry and the theories of the planets' (Carter \& McLaren, 1995, p. 36). Undergraduates such as Downie learnt about the terrestrial globe, continents and the measurement of latitude. The front cover of Downie's dictates includes a hand drawn terrestrial globe within which the continents of Europa, Africa, America and Asia have been drawn and named and lines of latitude inserted (Figure 5), an illustration of chorographical knowledge being communicated to students. Geography was taught in extra-mural classes available to undergraduates in the first half of the eighteenth century. Thomas Blackwell Jnr at 
Marischal College was, in the 1750s, giving 'a private class, for ancient History, Geography and Chronology' (Wood, 1993, p. 60"v). Thomas Gordon, Professor of Humanities at King's published a pamphlet dated $18^{\text {th }}$ September 1744 advertising that he took in undergraduate boarders (presumably to augment his salary) and provided additional classes for those living in his household as follows:

As those who board with Mr GORDON are so immediately under his Inspection, he spends several Hours a Day in instructing them in the Knowledge of History, Geography, Chronology, Heraldry, and the Principles of Drawing and Architecture. He takes Occasion to explain the System of the World, suitable to their weak Capacities, and whatever else in the learned Sciences is both instructing and amusing to younger minds (Wood, 1993, p. 58).

Geographical education at Marischal and King's Colleges had changed by the early 1750 s, a likely reflection of the changes in the arts curriculum at both institutions instituted in an attempt to increase student enrolments in the 1750s (Carter \& McLaren, 1995). Indeed a formal reform of curriculum was agreed by the regents and professors at Marischal College on $11^{\text {th }}$ January 1753 that changed the historic sequence of study, moving geographical education into the second year curriculum (Wood, 1993). At King's the internationally recognised 'common sense' philosopher Thomas Reid taught a course entitled 'The Elements of Geography' in 1752. Withers and Mayhew (2002, p. 23) report that it was 'delivered in four main parts: a general regional geography of the globe; the main lands and seas names; "A very few of the Most remarkable Things belonging to each Country or City", and accounts of the trade winds'. Reid is noted to have been of the view that students needed to have a useful education that would prepare them for important roles within society after graduation. Such a utilitarian perspective for geographical education is well exemplified by the growing importance of surveying and map-making skills from the late 1600s/early 1700s, when 'maps 
became hallmarks of an “enlightened” mind and nation' (Hewitt, 2011, p. 4).

Undergraduates studying at institutions such as King's and Marischal Colleges included the sons of landed, professional and merchant families for whom 'a theoretical knowledge of surveying was considered integral to the education of an enlightened gentleman' (Hewitt, 2011, p. 4). Across Scotland the agricultural improvement movement required a landowner 'to be able to commission and judge maps of his own estates' (Hewitt, 2011, p. 5). Wood (1993) provides further evidence of the utilitarian nature of geographical education, quoting a student who wrote of Robert Hamilton's geographical teaching at Marischal that 'in every part of the course ... the application of the principles [of geography] to the practical parts of life is pointed out and illustrated with examples' (ibid. p. 88). The inclusion of geography in a curriculum designed to promote 'useful knowledge' was, Withers and Mayhew (2002, p. 23) report, accompanied in the Scottish Universities by "two other "disciplinary" trends geography as a matter of civil history, or, as it was widely termed, "ancient geography", and geography as a part of mathematics'. The classes given by Thomas Blackwell Jnr at Marischal and by Thomas Gordon at King's, as listed in Table 1, illustrate these trends.

A handful of notable changes took place in the Aberdeen Universities prior to the amalgamation of King's and Marischal Colleges in 1860 and the major changes ushered in by the Universities (Scotland) Act of 1889. First, English had replaced Latin as the language of University teaching by the 1730s (Carter \& McLaren, 1995). Second, the regent system, whereby a single academic taught a cohort of undergraduates in all four years of their study was replaced by the professorial system of teaching, with a subject specialist teaching specific elements of the curricula. Third, the number of academic staff grew, albeit slowly, and established chairs were created in medicine and subjects other than the traditional disciplines of Divinity, Mathematics, Natural and 
Moral Philosophy. These changes notwithstanding, the Arts syllabus, and the geographical elements therein, continued to be taught at Aberdeen in a similar vein to that established following the reforms of the 1750 s.

\section{Impacts of the Universities (Scotland) Act, 1889}

The Universities (Scotland) Act, 1889, which came into operation in 1892, marked a restructuring of entrance requirements and degree regulations at the Scottish Universities. Concomitantly the University of Aberdeen first admitted women undergraduates in the 1890-91 academic session and the first female MA graduates were awarded their degrees in 1898. Of particular relevance to the development of geographical education at the University of Aberdeen following the 1892 Act are four points: (i) organisational changes led to the MA curriculum being opened up to allow students greater subject choice and many more began to take an Honours degree, specialising in a specific subject; (ii) increased specialisation led to the gradual appointment of staff in a wide range of disciplines and inter alia the creation of academic Departments; (iii) a BSc degree was introduced in 1892; (iv) geographical knowledge was required at entrance examination stage.

Reorganisation of the MA following the 1889 Act included specifying groups of subjects that must be passed to compile a graduating curriculum. Arts students were required to take a Pure Science class; Geology was one of the options and was delivered within the Department of Natural History (which was also responsible for the teaching of Botany and Zoology in the 1890s). Students who took the Ordinary Geology class in the period 1892-93 to 1900-01 were explicitly instructed in 'Physical Geography'. In the 1898-99 Calendar (p. 156) part (a) of the Geology course (the first 
of four parts) was described as 'Physical Geography, as bearing on Geology proper'. Students could be examined on any of the following topics:

The internal temperature of the Earth; Theories as to the Condition of the Earth's Interior; Origin and Distribution of Dry Land; Character and Mode of Formation of Mountain-chains; Phenomena of Volcanoes and Earthquakes; Rivers and Rivervalleys; Sub-areal denudation and its agents; the Sea and Marine Denudation; Ice and Ice-action (The University of Aberdeen University Calendar for 1898-99, p. 156)

In 1901-02 this section of the Ordinary Systematic Geology course was renamed 'Physical Geology' but the synopsis of classes describes the content as being the same as that taught in the 1890 s and the curriculum remained unaltered for many years. Students would have to wait for almost two decades before formal instruction in content explicitly described as 'Geography' would once again be available. The changing nomenclature could reflect the formalisation of academic disciplines and a desire by academics to exert their ownership over areas of knowledge within their discipline.

Withers (2001, p. 2014-15) reported that John Clarke, appointed Lecturer in Education in 1898, 'had been giving geography classes and publishing on the subject since 1898'. The Education syllabus, as set out in the University Calendars for the first two decades of the twentieth century, contain no references to content that could be described as 'geographical' in nature. Clarke may have given private classes, but no evidence for this has been found. Bridges (1985, p. 82) described John Clarke as 'a keen member and chairman of the [Aberdeen] branch [of the Royal Scottish Geographical Society - the RSGS]', who had done 'much to promote geographical teaching at other levels of study'. Geography was a school subject and Clarke's efforts to promote the discipline could have been directed at improving Geography's place within the Scottish primary and secondary school curriculum. 
The 1889 Universities (Scotland) Act ushered in formal procedures for University entrance; at Aberdeen, Ordnance No. 11, General no. 6, governed the preliminary examinations that had to be passed prior to a student entering the University as an undergraduate pursing either the degrees of Master of Arts or Bachelor of Science. Preliminary Examination candidates were required to pass examinations in English, Mathematics, and one of Latin, French, Italian, German and Dynamics. Geography was a named element of the English section of the preliminary examination along with History. Geography was taught in schools across Scotland in the nineteenth century, although the quality of that education, and the scope of what was taught was deemed poor in many quarters (see Pacione, 2014 for further details).

Those registering to take the preliminary examination for entry to Aberdeen University in the autumn of 1893 had been informed that they would be required to answer questions on 'general knowledge of the Geography of the World, and a special knowledge of the Geography of the British Empire' (Aberdeen University Calendar for the year 1893-94, p. 79). This provision remained in place until the four ancient Scottish Universities implemented changes to their admissions procedures for entry to academic session 1919-20. Copies of the preliminary examination papers were published in issues of the University Calendar. Examples of the questions set in the 'Geography' section of the Preliminary Examination in Arts and Science past papers for the English II paper in 1993 and 1913 are as follows:

1893 Q. 7 English (Second Paper).

Define the geographical terms: - Delta, bay, ness, sierra, steppe, debouchure, longitude.

Enumerate the counties of Scotland, and the chief rivers on the east coast of England, north of the Thames.

Where precisely are Benares, Zanzibar, Bologna, Lucerne?

(Source: The Aberdeen University Calendar for the year 1893-94, p. 192) 
March 1913 English (Second Paper) rubric instructed candidates: 'Seven, and not more than seven, questions are to be answered ... one from Section C'.

Section C

9 Draw a map of the Pacific Ocean, indicating British possessions.

10 Enumerate. in rough geographical order from North to South, the principal British coalfields, and name the towns specially connected with them.

11 Draw a rough map of the Turkish Empire as it existed in 1910, and mark its chief divisions, indicating those which have been the scene of recent wars

(Source: The Aberdeen University Calendar for the year 1913-14, p. 288).

The questions above reflect the 'descriptive enumeration of place information and landscape features' critiqued by those wishing to see the 'new Geography', based on analysis and explanation, firmly established in Scotland's schools and universities. By 1938 ample evidence for the 'new Geography' was to be found in the Preliminary Examination. Between 1919 and 1938 Geography was grouped under Natural Science in the Preliminary Examination, alongside Chemistry, Botany, and Zoology. Those seeking admission to the University in the late 1930s were advised that, in Spring 1938, those wishing to study Natural Science 'may take any two of the following papers set in the Leaving Certificate Examination of the Scottish Education Department, viz: Chemistry, Botany, Pure Zoology, Higher Geography' (The Aberdeen University Calendar for the year 1937-38, p. 102). Prospective applicants intending to sit the Autumn Preliminary Examination in Natural Science were required to answer two questions from four sections (Chemistry, Botany, Zoology and Geography) during a three hour paper. Details about the Geography paper for autumn 1938 are reproduced below. They are of interest because they illustrate knowledge of the 'new Geography' was now expected of school leavers wishing to enter University. 
'Candidates will be required to give evidence of ability to read and interpret Ordnance Survey Maps, especially those on the scale of one inch to one mile, and to present geographical information by means of sketch-maps and diagrams. (No special knowledge of methods of surveying or of technical cartography will be required.)

Candidates must further give evidence of knowledge of: -(1) The physical and biological basis of geography so far as is necessary for the understanding of the features of structure, of the elements of landscape, of climate, of natural and cultivated landscapes, of climate, of natural and cultivated vegetation, and of animal lives, which are of importance to the life of man.

(2) The Earth as whole with special reference to the relationships of the continent and to the proper perspective of the British Community of Nations.

(3) The British Isles as a region, in sufficient detail for the development and elucidation of general geographical principles.'

(Source: The Aberdeen University Calendar for the year 1937-38, p. 105)

Admission regulations were changed again in 1939, with Geography being grouped with English and History as approved Scottish Leaving Certificate subjects (The Aberdeen University Calendar for the year 1939-40). A further change was instigated post-World War II, with Geography then being grouped with History, Applied Sciences, Art and Music (The Aberdeen University Calendar for the year 1949$50)$.

The account presented above of the years following the Universities (Scotland) Act 1889 demonstrates that although geographical knowledge was expected of both Arts and Science students (the subject was included in the preliminary examination) and that Physical Geography topics were taught to students following MA and BSc curricula who included Ordinary/First Year Geology in their mix of courses, a named course, let alone a named degree programme in Geography, was not available. Active participation by members of University staff in the activities of the Aberdeen branch of the RSGS 
developed an interest in and awareness of 'the scholarly and scientific new Geography' (Bridges, 1985, p. 83) within Aberdeen's academic community. Bridges also suggests that the RSGS branch encouraged Geography to be viewed as an attractive subject amongst 'Aberdeen's civic, commercial and professional elite who supported the new branch'. This intersection of town and gown interest in Geography is quite likely to have underpinned the moves to establish formal geographical education in Aberdeen's university and the appointment of a named lecturer in Geography for the start of the academic session 1919-20.

\section{The establishment of a Department of Geography at the University of}

\section{Aberdeen}

George Adam Smith, minister of Queen's Cross Free Church of Scotland in Aberdeen in the 1880s, later the Principal of Aberdeen University (1909-35), played a prominent role in the Aberdeen branch of the RSGS following its inauguration in 1885. An academic theologian, Smith also made contributions to academic geography, notably his 1915 Atlas of the Historical Geography of the Holy Land. In the year he was appointed Principal he promised 'that the Society's [RSGS] long-felt wish to have Geography taught in the universities should be gratified at Aberdeen' (Bridges, 1985, p. 82). It was not until a decade later that this promise was realised, via the somewhat unusual route of town and gown support for, and public subscription to support financially, the establishment of a new Bachelor of Commerce degree at Aberdeen University.

In November 1918, the Aberdeen University Review (Volume 6, No. 16), published proposals for a new 'Degree in Commerce' (p. 70), and reported that 'Members of the Aberdeen Chamber of Commerce and friends interested have subscribed $£ 10,506$ towards the cost of establishing a Faculty of Commerce in the 
University; and we understand that another individual subscription of $£ 5000$ has been promised' (ibid.). The relevance of this announcement to the development of formal geographical education becomes clear in an item published in the succeeding issue of the Review (Volume 6, No. 17) in which details about the establishment of a new undergraduate degree, a Bachelor of Commerce (BCom.), were set out (see Figure 6). 'Economic Geography' was named as a compulsory course for the new degree and provisions for new lectureships to support the BCom, including central University funding for a new lectureship in Geography, were announced.

The next issue of the Review (Volume 6, No. 18, June 1919) formally announced the creation of six new lectureships, including one in Geography. John McFarlane, MA, MCom applied for the lectureship on the $5^{\text {th }}$ July 1919 (McFarlane family, pers. com.). McFarlane's wife noted in her diary on the $16^{\text {th }}$ July 1919 that in a letter received that day her husband was informed 'I have pleasure in informing you that at its meeting yesterday the University of Aberdeen Court unanimously appointed you Lecturer in Geography at a salary of $£ 600$ '. The first Aberdeen University Lecturer in Geography gave his inaugural lecture at $4.00 \mathrm{pm}$ on the $17^{\text {th }}$ October 1919 at the start of the Autumn term. McFarlane's appointment marked the establishment of a Department of Geography at Aberdeen, the third such department at a Scottish University ${ }^{\text {vi }}$.

\subsection{The early years of a Geography Department at Aberdeen: establishing MA and BSc degrees in Geography}

Born in Aberlady, East Lothian, McFarlane attended school in East Linton before attending the University of Edinburgh where he graduated in 1897 with First Class Honours in History. Awarded a Vans Dunlop Scholarship, he moved to King's College Cambridge as an exhibitioner and graduated in 1902 with Honours in History and 
Economics. Perhaps unsurprisingly, his first academic post was as Lecturer in History at St David's College, Lampeter (University of Wales) from 1903-04. His economic and presumably geographical interests were reflected in appointment to a Lectureship in Economic and Political Geography at the University of Manchester in 1904, followed by 'transformation' to Lecturer in Geography in 1906 (Freeman, 1984). His interests in Economic and Political Geography, coupled with being the author of a successful text book Economic Geography and holding the degree of M.Com. (awarding institution not known but perhaps Manchester), must have made him an attractive proposition to a University establishing a new Bachelor of Commerce degree. McFarlane had served in the Geographical Section of the Naval Intelligence Division during the First World War (O’Dell, 1953), one of few professional geographers to do so. The first of five editions

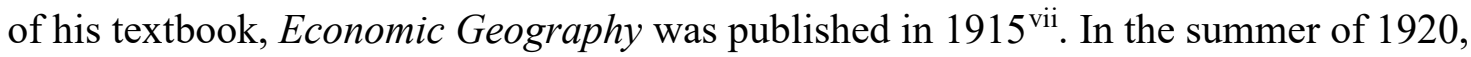
a year after he took up his position in Aberdeen, he served as President of Section E Geography at the British Association meeting in Cardiff where his Presidential Address focused on geographical conditions associated with 'changes wrought on the map of Europe by the Great War' (McFarlane, 1920, p. 98). Post-war events also formed the basis of his 1920 paper entitled Geographers and the Reconstruction of Europe published in Nature. Appointed as lecturer in 1919, McFarlane was promoted to Reader in 1923 in recognition of his academic standing.

The first Geography class to be taught at Aberdeen, in academic session 201920, was Ordinary Economic Geography, comprising three lectures a week delivered during the Winter and Spring Terms with 'a tutorial class for those who desire to attend ... held once a week' (Aberdeen University Calendar 1920-21, p. 100). The synopsis of the class clearly shows how the course content aligned with the BCom degree and illustrates a strong Regional Geography emphasis: 
The lectures will deal with the influences of geographical factors on economic development. Surface features and place relations. The distribution of soils and minerals. Climate and the conditions by which it is determined. The influence of climate upon vegetation; the cultivation of plants of economic value. The distribution of population and the growth of industry. Development of communications. Foreign Trade.

Special attention will be given to Europe, North and South America and the Monsoon Countries of Asia.

Books recommended: The Lecturer's Economic Geography; Chisholms' Commercial Geography; Russell Smith's Industrial and Commercial Geography; The Oxford Survey of the British Empire, chapters on economic conditions in Canada, India, Australia, and South Africa; Partich's Central Europe (Source: The Aberdeen University Calendar for the year 1920-21, p. 100).

Thirty students took Economic Geography the first year it was offered. The syllabus for an Honours degree in Geography, open to MA and BSc candidates, was published in advance of students entering the University in academic session 1920-21. The Ordinary Geography and Economic Geography classes were both offered for two years, but in 1922-23 the latter was withdrawn and Ordinary Geography, taught over three terms, became the Geographical element of the BCom. degree. The Honours Geography syllabus, launched in 1920-21, is presented in Figure 7.

In 1921-22 lists of recommended reading were added to the Geography 'Synopsis of Classes' detailed in the University Calendar. The reading lists (reproduced in Appendix 1) provide further insight into the curriculum McFarlane introduced, as do early Geography examination papers. In June 1926 Ordinary (first year) Geography candidates were required to sit two papers each of three hours duration. They were instructed that not more than FIVE questions be attempted and were given a choice of nine questions to choose from in each paper. The questions were framed such that almost every region of the world featured, and the themes included climate and vegetation, industrial location and activity, factors behind urbanisation, population 
distribution and density in specific national contexts, means of delineating 'natural regions' and topographic mapping and surveying viii. Field excursions were regular events for Geography undergraduates. McFarlane's wife Helen (known as Ella) recorded that her husband took students to Edzell in March 1927 and May 1929 and the latter visit must have prompted inclusion of the following question in the June 1929 Geography (Ordinary) paper: Q8 Describe and account for the scenery of Glenesk. The McFarlane family have a handful of photographs of student excursions from the first decades of the Geography department and two are reproduced in Figure 8.

Contemporary ideas in the discipline, concepts that feature in most undergraduate courses today that chart the history and philosophy of the discipline, were examined in the Advanced (second year) examination. For example, in June 1925 the Geography (Advanced) - Paper 2 contained the following: Q9.- Compare the views of Miss Semple and M. Febvre on the influence of geographical environment. A year later students were asked this: Q7.- To what extent do you consider it possible to establish a science of human geography?

The overall scope of the Geography syllabus remained largely the same throughout McFarlane's period in office. However, the regional focus of the Advanced Class was reviewed on a regular basis and the prescribed reading was updated regularly, indicating that McFarlane was a teacher who kept abreast of new publications. Between 1921-22 and 1926-27 the regions focused upon were Europe and North America (see Appendix 2 for an illustration of examination questions when North America was the region of focus for the Advanced Class of session 1924-25). Between 1927-28 and 1931-32 the Advanced Class studied the British Empire with the recommended reading indicating that Canada, Australia, India and Great Britain were the focus of study. In academic year 1932-33 this switched to India and the United States. In 1932-33 it was 
Asia, between 1933-34 and 1936-37 it was the Far East, in 1937-39 the Far East and the United States of America were the regional focus and Africa and North America in 1939-40 and 1943-44.

The University Calendar, published each academic year, set out the regulations for Ordinary and Honours Geography MA and BSc degrees. The regulations provide an indication of the subjects with which Geography was considered to be cognate (Geology, History, Political Economy) as well as, for the MA curriculum in particular, the breadth of study that was required of all undergraduate students. In the year 192122, the first year that the Advanced Geography class was available to MA and BSc students, the regulations outlined the order in which courses should be studied and the combinations of classes that were permitted for students intending to pursue a MA or BSc degree in Geography. These are reproduced in Appendix 3.

For the MA, the prescriptions produced above remained in place until after World War II with Honours degrees appearing to follow a 'Major Subject - Minor Subject' structure. History and Political Economy were joined by Anthropology in session 1942-43 as the supplementary Honours subjects for Geography students. These subjects remain popular today with many MA Geography students taking them alongside Geography courses in their first or second year. Joint Honours degrees combining Geography with these subjects are also common in the MA degree programme.

As well as containing information about syllabi and lecture hours, the University Calendars include details of the format of the final Geography Honours examinations. In 1943-44, for example, Honours candidate were required to sit seven three-hour written examinations (two papers on General and Regional Geography, two on Subjects of the Honours Course in Geography, one paper on Geology, two on History or Political 
Economy or Anthropology). They also had to complete an essay, a thesis and sit a practical examination in which they were most likely questioned about map work.

The early years of a Geography Department at Aberdeen: consolidating student numbers

During the first half of the twentieth century it was not uncommon for academic departments to be very small, often staffed by a single person. Aberdeen did not directly follow the pattern of formalising geographical education that occurred in the other Scottish, English and Welsh Universities (Stoddart, 1986; Withers, 2001) whereby 'an initial appointment, of a single person, teaching the subject at diploma level or as part of the general MA or BSc degree [preceded the] establishment of a honours school' (Withers, 2001, p. 204). As narrated above, the catalyst for McFarlane's appointment was the establishment of a BCom degree with a full Honours Geography programme adopted in University regulations a year later. The Economic Geography class ran for three years, attracting 30 students in 1919-20, 14 in 1920-21 and 9 in 1921-22. Content from the Economic Geography class was absorbed into the Ordinary Geography class for delivery from 1922-23 onwards, avoiding duplication of effort and providing a broader geographical education to students following the BCom programme than had been offered in a course considering only economic geography.

Geography quickly became a very popular Ordinary course (the equivalent of a first year University course today), although numbers taking the Advanced course (the equivalent of a second year course) were small (Figure 9). Undergraduate numbers in Geography's first 25 years peaked in 1930-31. In this academic year there were 1,314 students matriculated at the University, 646 in Arts and 267 in Science. The 81 Geography students represented six per cent of the student body. Student numbers in 
Geography dipped in the 1930s, reflecting the Scotland-wide drop in undergraduate numbers across all subjects (most likely a reflection of the lower birth rate during and immediately after World War I, leading to fewer young adults of University age at this time, and the economic depression affecting the United Kingdom. From 1901 the Carnegie endowment paid the university fees of all Scottish students who applied for funding; means testing was not used (Anderson, 1988). Living costs, however, had to be met by the student. Many families in Aberdeen and the North East of Scotland, the traditional recruiting ground for the University of Aberdeen, would have struggled to accommodate the loss of potential income to the household that sending a school leaver to university would entail. The economic situation in the late 1920 s and early 1930 s would have brought such household financial decision making into sharp focus in and around Aberdeen and elsewhere in the UK. The outbreak of hostilities in 1939 led to a notable decrease in student numbers in the Ordinary Geography class in particular; this contraction in undergraduate numbers mirrored the nationwide pattern as young men and women and many academic staff were conscripted for military service or required for civilian roles in support of the war effort.

The first students to graduate with an Honours Degree in Geography did so in the summer of 1928, they were Mr G.R.B Baillie and Miss E. Madeleine Duncan. Baillie's dissertation was entitled 'Mainland of Orkney' and Duncan's was 'Dee Valley and Bordering Uplands'. Fifteen Honours Geography students graduated during the Department's first 25 years, 11 men and four women. The first candidate for a research degree in Geography matriculated in sessions 1931-32, 1932-33 and 1933-34. Unfortunately the student is not named. Graduation Lists published in the University Calendar name those awarded the degree of Doctor of Philosophy and the title of their thesis, but do not identify the discipline of those awarded doctorates. From this 
information two possible candidates who received doctorates in 1936 were identified as potentially the first to be awarded a $\mathrm{PhD}$ in Geography. Further investigations suggested they were historians. It is highly probable that the first doctoral candidate to be awarded the degree of PhD in Geography was Kenneth Walton (see below) in 1951.

Despite healthy student numbers, McFarlane was to be the only full time member of lecturing staff in Geography at Aberdeen for his entire period in office (1919-1945). Student numbers were such that a case for additional staff resource was answered in 1929-30 with the appointment of a part-time Assistant Lecturer in Geography. Alexander Bremner, MA, DSc (Edin), FRSE held this position for eleven years (see the contribution of Soulsby et al. in this Special Issue for details of the contribution Bremner made to pioneering studies of rivers). The Assistant Lectureship in Geography was vacant between 1941-42 and 1945-46 and not included in the staff list for 1946-47. A posthumous reminiscence on McFarlane's 26-year period as Head of Department identified many disappointments he faced, including the failure to secure additional full-time lectureships (other than the often precarious, time-limited Assistant Lectureship) for his discipline:

... when lack of funds or other severe impediment retarded the fulfilment of his great ambition, to have in Aberdeen University an efficient, smooth-running, wellstaffed and well-equipped Geography department. The completion of this great task he eventually ensured, although the last two of his aims were fulfilled only after he demitted office (Aberdeen University Review, 1960, p. 387).

As well as discharging his teaching duties, McFarlane was active in wider University life and that of the British academic community. In 1926 McFarlane became a member of the Senatus Academicus, one of only a handful of non-Professorial members of the body that effectively governed the University. His seniority amongst the academic staff is further illustrated by the fact that he held the position of Convenor of 
the University Appointments Committee for a number of years in the late 1930s. Throughout his career McFarlane was a regular delegate at annual meetings of the British Association for the Advancement of Science ${ }^{i x}$. The 104th annual meeting of the British Association took place, in September 1934, in Aberdeen and McFarlane was 'a genial host' (O’Dell, 1953). At this meeting Section E - Geography had 27 papers delivered over five days (the Section E president in 1934 was Alan G. Ogilvie, Edinburgh University's Professor of Geography). McFarlane presented a paper entitled 'The basins of the Dee and the Don'. Andrew O'Dell, who was to join Aberdeen University a decade later, spoke on 'Population changes in Aberdeenshire from the Union to the present time'. In addition to the paper sessions, Section E delegates could take excursions that took in locations across North East Scotland. It is probable that these excursions followed routes used for undergraduate Geography fieldtrips in the 1920s and 1930s. It was normal for the local committee responsible for hosting a BA meeting to prepare a volume showcasing the city and wider region hosting the event. The 1934 volume, A scientific survey of Aberdeen and District, included a chapter written by McFarlane entitled 'Geography of the North-East'.

\section{The post-World War II years}

The immediate post-World War II period was one of profound change in Higher Education across the UK. The post-war Labour government actively promoted an increase in student numbers, and in Scotland local Councils introduced student bursaries which provided funds from which undergraduate students could pay their tuition fees and meet day to day living costs. As noted above, Scottish domiciled students had previously been able to access the Carnegie endowment to meet the cost of tuition fees, 
but the provision of maintenance grants allowed University attendance to be opened up to students from families who otherwise would have been unable to meet the costs of participating in Higher Education. As a result, the undergraduate population became more numerous and more diverse and in the 1940s school leavers were joined on campus by men and women recently demobilised. The post-war years were ones of profound change for Geography at Aberdeen. Staff numbers increased. Student numbers, especially Honours student numbers, also rose and the Department relocated from rooms in Marischal College to Old Aberdeen.

\section{A new Head of Department and growing numbers of Geography staff}

Andrew O’Dell replaced John McFarlane. Born in the Transvaal (but with family connections in the Scottish Borders), O’Dell studied at the Joint School of Geography at the University of London based at King's College and the London School of Economics. In the 1930s he held a part-time position at Birkbeck College, University of London and completed, in 1933, a MSc by research at the London School of Economics on the Historical Geography of the Shetland Islands. Shetland was to feature repeatedly in his academic career and in the education of Aberdeen Geography students in the 1950s and 1960s. He had a solid publication record by the time he was eventually appointed to a lectureship in Geography at Birkbeck College in 1937. During the Second World War O'Dell was a member of a team of scholars who produced the British Naval Intelligence Division Geographical Handbook Series. Comprising 31 titles published as 58 volumes, these publications were intended for the use of all the British Armed Forces to promote Allied Forces interests. They provided information on physical features, relief, climate, history, administrative information, population, 
economic geography and details of ports and communications about the county or other spatial grouping under consideration (Gosme, 2000). Between 1943 and 1945 O'Dell was a Research Officer in the Department of Health for Scotland, during which time it was noted that he 'acquired a sensitive appreciation of Scottish economic problems, especially in the central Lowlands' (Anonymous 1967, p. 190). O’Dell was a well established member of the UK's geographical community by the time he secured the position of lecturer and Head of the Department of Geography in 1945. He became a non-professorial member of the Senatus Academicus in 1947, was promoted to Reader in Geography in 1949, and he became the first holder of the new Chair in Geography, established in 1951.

It was under O'Dell's leadership that the Geography Department underwent considerable growth, becoming a prominent and influential Department within the University and fulfilling ambitions for the Department McFarlane had long hoped to achieve. Within five years O’Dell was leading a Department of five academic staff. Winifred Day ${ }^{\mathrm{x}}$ was appointed full-time assistant lecturer in 1947, holding the post for four years. William (Bill) Fisher was appointed lecturer in 1948, Kenneth (Ken) Walton and William (Bill) Kirk were both appointed to lectureships in 1949. Francis Synge was appointed Cartographer in 1950. In addition to their teaching duties, the members of the Geography Department all pursued their own programmes of research creating a department known both for high student numbers and its research outputs. A full staff list covering the period 1919 to date is presented as Appendix 4.

More staff facilitated the teaching of the growing numbers of Geography undergraduates and allowed a more diverse curriculum to be offered in which the research interests of the academic staff could be represented. Regulations for a degree in Geography were revised in the immediate post-war period. The 1949-50 University 
Calendar sets out the revised order of study for the MA Honours Geography degree that stipulated 'During their first year of study, students are strongly recommended to take the Ordinary Course in Botany or Geology as one of the two outside subjects. In addition to the Advanced Course in the second year, students will attend a class on cartographic methods; in the third year, students will attend Courses on Advanced Physical Basis (including Social Science) and Social Geography, in the fourth year, Courses on their Special Subject and Historical Geography' for 1949-50, p. 135). This revision to the curriculum is indicative of Geography being understood as a subject that required knowledge of 'natural science', 'social science' and more traditional arts subjects. The structure of Honours Degree examinations at Aberdeen were revised in the immediate post-war period. The 'major-minor' structure was replaced by examinations exclusively based on subject matter from the Honours discipline. The format outlined for students intending to graduate MA with Honours in Geography in 1950 and 1951 was described in The Aberdeen University Calendar for the Year 194950. The examination comprised six written papers (two papers on General Geography to include the physical basis and economic geography, two Comparative Regional Geography papers, a paper on the Geography of the British Isles and a Special Subject paper). In addition there was a practical examination on map work and students were required to submit a thesis on an approved area (i.e. a regional study). The strong focus on regional Geography remained in place for two decades.

\section{Immediate post-war growth in student numbers}

The growth of undergraduate numbers in the late 1940s and early 1950s is recorded in class totals published in The Aberdeen University Calendar and details of the 
undergraduate population reported annually in 'Year in the Department' articles within The Orb (the Journal of the Aberdeen University Geographical Society, more of which below). The numbers taking Ordinary and Science Class 1 Geography quickly returned to pre-war levels. Numbers taking Advanced and Science Class 2 Geography grew markedly: the largest pre-war Advanced Geography class comprised six students, in 1947-48 there were 20. At a time when most students would graduate with an Ordinary degree, Honours Geography numbers in the early 1950s were large. The 1964 issue of The Orb published a list of names, year of graduation and the last known employment status of the post-war Honours graduates. The list was compiled by James (Jimmy) Coull, then Lecturer in Geography. The majority of Geography graduates were male (134 out of the 177 listed), but as illustrated in Figure 10, the trend was for women to comprise an increasing proportion of the Honours graduates as the post-war period progressed.

School teaching was the most common occupation entered into by the post-war graduates with 84 of the 177 listed in Coull's report as teachers or attending teacher training college. Female graduates were as likely as male graduates to enter the teaching profession. The post-war graduates could take advantage of changes in the structure of post-primary school level education in Scotland. Most Junior Secondary pupils left school aged 15 without completing Leaving Certificate examinations. The curriculum of Senior Secondary pupils was orientated towards entry to the Scottish Higher and Lower examinations. With more pupils in the 'academic' Leaving Certificate stream there was an increased demand for subject specialist teachers who had completed an Honours degree in their subject. Honours graduates continued to enter the teaching profession in large numbness for the remainder of the 1960s and into the 1970s, reflecting the 'huge growth in the teaching profession [in Scotland] of over 20 per cent between 1963 and 
1973’ (Devine, 1999, p. 580). Strikingly, 34 (almost a fifth) of the post-war Aberdeen Geography graduates were reported by Coull to be in lecturing or research posts in Higher Education or research institutes in the UK and abroad. None of these posts were held by female graduates. A career in business or industry had been pursued by 15,10 were in local government or civil service posts, four of which were overseas, five had entered the church, four were town planners (three of whom were women), four were employed as soil surveyors, and two were pilots (one Royal Air Force and one British Aerospace).

\section{Relocating the department: the move from Marischal College to Old Aberdeen}

Increasing numbers of staff and students meant that, by the end of the 1940s, Geography (and other academic departments at Aberdeen) were desperately in need of more space. In time for the start of the new academic session, the Department of Geography relocated from the attic floors of Marischal College to Old Aberdeen. St Mary's, the former Free Church of Scotland building on the High Street, had been acquired by the University and was refurbished to provide offices and teaching rooms for the departments of Geography, Psychology, Law and Education. An account of the move to St Mary's was provided by O'Dell in 'The Year in the Department' published in the 1950 issue of The Orb in which he extols the creation of new laboratory space, containing state of the art equipment:

Since the last issue of THE ORB, the most spectacular change experienced by students and staff has been the removal from the heights at Marischal to the ground floor of St Mary's, Old Aberdeen. Throughout the Session 1948-9 removal was officially regarded as imminent but it only materialised the day before the present session commenced. For several weeks, until vital items were finished, geographers were to be found in Divinity and Latin classrooms, but by the 
beginning of the Spring Term, things began to flow more smoothly. Among the features of the new Department is a laboratory of revolutionary design which allows the staff to reach even the shyest members of the practical class. Included in the generous equipment are a Dines Anemometer, earth sculpture tank, wave-tank, individual tracing desks and a valuable range of visual instruction apparatus. The map and atlas stock has been enriched by a number of gifts from various donors (O’Dell, 1950, p. 1)

In reminiscences included in the festschrift marking the retirement of Roy Mellor, Bill Kirk (1986) recounted that the Head of Department, secretarial and technical staff were accommodated in St Mary's, along with teaching rooms and laboratory spaces. Other staff had their offices down the High Street in the Old Brewery, not moving into St Mary’s until 1964 when Law and Psychology moved out and St Mary's became the exclusive domain of the Department of Geography. The dispersed housing for Geography's academic staff was because, Kirk recalled, shared offices in St Mary's were cramped, and there was soon no space, exacerbated because:

... the professor [O'Dell] had developed a passion for maps. At his invitation crates of unwanted maps began to arrive from the Royal Geographical Society map-room and solicitors and estate agents emptied their vaults into the department, while any money left in the departmental account at the end of the year was used to swell an enormous collection of Admiralty Charts (Kirk, 1996, p. 4).

St Mary's remains the home of the Department, although the (much expanded) building is now shared with Archaeology and a few staff from Geology (the three disciplines currently constitute the School of Geosciences). Much of the map collection accumulated by O'Dell remains in map cabinets in 'Map Control' and in other depositories located throughout the old church and first extension of the building. Many items of value and/or particular historical interest were moved to the Special Collections unit of the University's Sir Duncan Rice Library a number of years ago. At the time of 
writing the future of the printed map collection is uncertain: digitisation and easy online access to historic, contemporary and specialist map collections means physical collections are no longer used as extensively as they once were.

Alongside a new physical home for the department and steadily increasing staff and student numbers, the post-war period marked the start of other activities that were to feature in Departmental life for decades to come. Two such activities are now considered, namely the launch of a student Journal, The Orb, and the establishment of scientific expeditions as core departmental activities.

\section{The Orb}

The first issue of the Aberdeen University Geographical Society Journal, The Orb, was published in May 1949 (see Figure 11) and it continued to be published on an annual basis until 1986. The Orb was produced by an editorial committee drawn from the student community and contained articles on a wide range of topics written mostly by students (undergraduate and postgraduate), but contributions from staff were also commonplace. The Head of Department contributed an annual 'Year in the Department' feature, in which student numbers and staff arrivals and departures were recorded, visits to the Department by domestic and international scholars were listed, publications and other research activities associated with members of staff were noted, field excursions were listed and other significant events in Departmental life were reported. As time passed the length of the 'Year in the Department' features grew, indicative of a vibrant, expanding and forward looking department. Institutional histories are often not written down in a formal record or, if they were recorded, the accounts were in documents long since destroyed. Without The Orb, key moments in Geography's history at Aberdeen in 
the 1950 s and 1960s might have remained unknown.

\subsection{The undergraduate geography curriculum and field excursions}

Field excursions for Geography students were elements of the curriculum under the leadership of John McFarlane (see above and Figure 8), but there is no information about these activities in archival materials held in the University. However, field excursions in the post-war period are documented, in the Head of Department's 'The Year in The Department' and pieces authored by students published in issues of The Orb. The post-war Geography degree regulations also make note of fieldwork being integral to study in the discipline, an element of a student's curriculum that would incur costs above those of annual tuition fees (which for both the MA and BSc were $£ 8$ ss $0 \mathrm{~d}$ for the academic session 1949-50). The 1949-50 Regulations for the Ordinary MA degree include a footnote stating 'In Geography and certain 'Science' subjects, extra expenses will be incurred both during the terms and in vacations on excursions and fieldwork which are essential parts of the various courses. Before entering on any such course of study, students should consult the Head of the Department concerned' (ibid., p. 129). Students studying for a BSc with Geography in their curriculum were advised in the regulations that 'Field excursions in Geology and Geography are compulsory as part of the courses and attendance on these will be taken into account when granting Class Certificates' (ibid., p. 252).

'The Year in the Department' entries in The Orb chronicle the locations of Easter and other trips. During the Easter vacation in 1948, 52 students and staff visited Edinburgh, York and Dent, Cumbria. The following year First and Second year students went to St Andrews and Honours students visited Shetland. At Easter 1951, the trip to 
Elgin was noted to have had an 'experiment of using bicycles' which 'was successful' (The Orb, Vol. 1. No. 4.). The central place of field excursions in the geographical education provided at Aberdeen is illustrated in the account of fieldwork conducted in 1958: 'The Easter 1958 field week was held at Forres and Moy. Over 60 students took part in preliminary preparation for the Department's hydrological survey of the river Findhorn. Considerable experience was gained in field mapping of land use and landforms' (The Orb Vol. 2. No. 2).

\section{Scientific expeditions}

The immediate post-war period was also one in which a tradition of staff and student scientific expeditions commenced. The Aberdeen University Exploration Committee was established in December 1949, inspired by a lecture to Geography staff and students given by Johnnie Buchan, Lord Tweedsmuir ${ }^{x i}$, then Rector of the University, during a visit to the Departments new home in St Mary's. The University Expedition Group's first overseas venture was to Cyrenaica (the eastern coastal region of Libya) in the autumn of 1951. The expedition was led by Bill Fisher, Ken Walton was second in command and seven Geography students completed the Departmental members of the party. Staff from three other departments in the University (Botany, Natural History and Classics) participated: it was an interdisciplinary venture, but one with Geographical objectives at its core. Fisher (1952, p. 57) gave the following account of the first expedition:

At the inspiration of the then Lord Rector, Lord Tweedsmuir, and with the active support of Principal T. M. Taylor, the idea of an Aberdeen University Expedition abroad took shape during 1950-51. Foreign Office interest, and most generous financial backing from the University Court and the Carnegie Trust, made the 
proposals a reality; hence on September $16^{\text {th }}, 1951$, eleven graduate and student members of the University assembled in London for the first stage of a journey to Benghazi, Cyrenaica, by Foreign Office charter aeroplane. The main basis of the Expedition was geographical, but representatives of the Botany, Classics, and Natural History Departments also took part .... General direction of the Expedition was in the hands of Senatus Committee, presided over by the Principal. And it was laid down that, in addition to field survey of various kinds, the venture should emphasise, independently of any scientific results, the broader objective of giving each member as wide an acquaintance as possible with conditions and ways of life in the country.

Three papers about the expedition were published in the forerunner of Scottish Geographical Journal, the Scottish Geographical Magazine (Fisher, 1952; Walton,

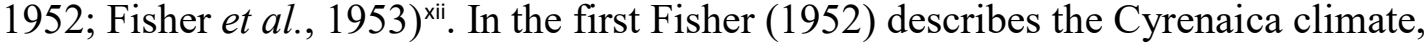
geomorphology, archaeology, flora and fauna. In the second contribution Walton (1952) presents accounts of the oasis of Jalo, including findings relating to water supply, agriculture and gardening, housing and population. The third paper, co-authored by Fisher and two students, focuses on the ancient city of Cyrene, the Roman reservoir of Saf Saf and the town of Derna. Fisher reflects that 'the value from a first visit to Africa lay in the personal experience gained, as well as in the achievement of any scientific results' (1952, p. 63), sentiments that translate in full to the value contemporary geography undergraduates gain from international fieldwork. The Cyranacia team's reception hosted by King Idri at the Royal Palace of Benghazi is, however, a student experience unlikely to be surpassed on present day expeditions!

Other scientific expeditions took place closer to home. For example, in the summer of 1951 Bill Kirk supervised the archaeological excavation of a site at Forvie, and geographers were involved in a multi-department study of Vedal in Norway in 1953. These activities pale into insignificance when compared with the University Geographical Society's excavations at St Ninian's Isle, Shetland. As noted above, 
O'Dell had a long association with Shetland and led student excursions there from the late 1940s. In 1955, excavations commenced with the aim of locating a medieval chapel on St Ninan's Isle. A small church dating from the $8^{\text {th }}$ Century was found and, in 1958, the team discovered finds of international significance - 28 silver and silver-gilt objects. A rather understated account of the discovery was reported by O'Dell in his 'The Year in the Department' entry for The Orb, Vol 2, No. 2 March 1959. He wrote:

\begin{abstract}
A highlight of the year has been the discovery of the unique hoard of silverware on the site of the University Geographical Society's excavations at St. Ninian's Isle, Shetland. The discovery marked the successful end of the fourth seasons' work. The hoard, described in this issue, has aroused wide public interest. It has been described in a number of public lectures and articles and was on public display at the British Museum, London. Members of the expedition took part in a thirty minute broadcast in the B.B.C.'s Network Three programme.
\end{abstract}

O'Dell had advocated for the eventual return of the hoard to the Shetland Islands. Referred to as the St Ninian's Isle Treasure and thought to be Pictish, the objects uncovered by O'Dell's team are now on display in the National Museum of Scotland in Edinburgh ${ }^{\text {xiii }}$. O'Dell's involvement in archaeology and Shetland was undoubtedly instrumental in the formation of the first ever Viking Congress meeting, held in Lerwick in 1950. The Congress is the premier pan-European Viking-related academic symposium. The 1950 meeting was organised by three people based in Aberdeen - the University librarian W. Douglas Simpson, A.C. Davis of the British Council and O’Dell ${ }^{\text {iv }}$ (see Figure 12).

The post-war period closed with the Department of Geography having established itself as a very active academic unit within the University. Further expansion and a growing research profile were to come in the following decades. 


\section{The 1960s: a decade of unprecedented expansion in British Higher Education}

The 1960s was a decade of hitherto unprecedented growth in Higher Education across the UK and the national trend was mirrored at Aberdeen University. The (UK wide) University Grants Committee (UGC) enquired, in 1960, 'whether the University could contribute to the national need for another 36,000 to 40,000 places for University students by about 1970 . The University agreed to the plan on the assumption that its numbers would rise to 4,500 of whom 500 would be postgraduates' (University of Aberdeen, 1963, pp. 15-16). The development plans reported in that publication anticipated the recommendations of the Robbins Report of 1963. Robbins had been charged with leading a review of the pattern of British full time Higher Education and a core recommendation was that the proportion of British school leavers going on to University should increase from around 5\% to at least $10 \%$ in the short term and, by the 1980s, around 15\%. The Labour Government of the day accepted the Robbins recommendations and additional funding was released for the Higher Education sector to fund additional student numbers, the development of new campus buildings and the creation of more Universities ${ }^{x v}$.

In 1955-56 1,890 students were registered at the University of Aberdeen, three quarters of whom came from Aberdeen or elsewhere in North East Scotland and half of whom lived at home (University of Aberdeen, 1963). The growth in student numbers and shifting pattern of domiciliary distribution of the institution's students were charted in The Orb between 1961 and 1968 ${ }^{\text {xi }}$. During the 1960-61 session the total student population at Aberdeen was 2,198, of whom 38\% were domiciled in Aberdeen City and a further $25 \%$ were domiciled elsewhere in North East Scotland (the former counties of Aberdeenshire, Moray, Banff and Kincardine). By 1967-68 the student population had grown to 5,035 , a $117 \%$ increase over seven years, and the proportion of 'local' students 
had decreased (25\% were from Aberdeen City, 24\% from elsewhere in the North East). The proportion of students from elsewhere in Scotland more than doubled between 1960 and 1967, perhaps in response to the introduction of Scottish Education Department grants in 1961-62. These standardised the grant available to students where previously individual councils had paid grants of variable value ${ }^{x v i i}$, and they also removed the condition imposed by some local authorities, including Aberdeen City, whereby grants would only be given for study locally unless the course a student wished to pursue was only available elsewhere. Unfortunately details of Geography's student numbers and their domiciliary status did not accompany the institution-wide analysis published in The Orb. Other sources of information reflect a picture of expansion, and growth in Geography student numbers in the 1960s, of a magnitude few would have considered possible just a decade before, are considered below. With a slight time lag, staff numbers and those of research students started to grow. Space for teaching and to house members of staff became a critical issue, resulting firstly in St Mary's being 'taken over' by Geographers and the first extension being planned and constructed. The 1960s also mark the Geography Department becoming responsible for the management of Tarradale House, familiar to many cohorts of Geography students (from Aberdeen and from other institutions) as the location for field courses.

\section{Student numbers quadruple, staff numbers treble}

Aberdeen's contribution to meeting the increase in student numbers made possible by increased UGC funding is well illustrated by the dramatic increase in Geography undergraduates during the 1960s (Figure 13). In 1955-56 there were 56 undergraduate Geography students. The number had increased to 107 by $1959-60$ and, a decade later, 
had more than quadrupled to 473. Session 1968-69 marked Geography's first venture into taught postgraduate education, leading the delivery of a two-year MSc course in

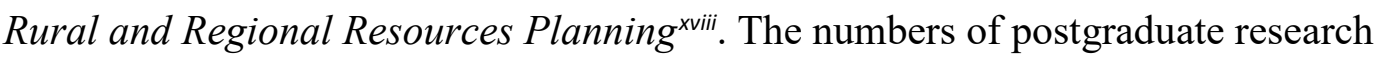
students working for MLitt and PhD degrees also grew in the mid to late 1960s. Postgraduate education is considered further below.

Growing undergraduate numbers in the 1950s placed considerable pressure on the academic staff to deliver the Geography teaching programme. At the start of academic session 1955-56, the Geography staff comprised four individuals, Andrew O'Dell, Chair and Head of Department, Ken Walton and Archibald McPherson, both Lecturers, and John Clarke as Assistant Lecturer. Five years later, in session 1960-61, student numbers had doubled but staff numbers had only increased by one (O'Dell and Walton had been joined by Roy Mellor and Archibald Fraser as Lecturers and Jimmy Coull had been appointed Assistant Lecturer), the same number in post as in the early 1950s. As illustrated in Figure 14 though, for the remainder of the 1960s core academic staff numbers grew almost every year (and continued to do so until 1979). In session 1969-70 the Geography academic staff complement had reached 17, comprising two Professors (Ken Walton - then Head of Department following the sudden death in post of Andrew O'Dell in 1967 - and Roy Mellor), one Senior Lecturer (Ronald Jones), ten Lecturers (Chalmers Clapperton, Jimmy Coull, Patrick (Pat) Hamilton, Eric Naylor, William (Bill) Ritchie, E. Alistair Smith, John S. Smith, Jeffrey (Jeff) Stone, David Sugden and Michael (Mike) Wood) and four Assistant Lecturers (John Farrington, Allan Hill, Alexander (Sandy) Mather, and Robert (Bobby) Wright). There were also two research assistants (Sheila Bain and Roger Crofts), a cartographer (Heather Lyall, née Smith) and two drawing room assistants (Moira Hunter and Marlene Smith). In 
addition, there were some junior technicians and administrative/secretarial staff who, unfortunately, are not all named in issues of The Orb.

A number of the new staff appointments in the 1960s were recent graduates of the department. Jimmy Coull graduated top of his class and was awarded the Royal Scottish Geographical Society's Silver Medal in the summer of 1959. He had also been the recipient of the John McFarlane Prize at the end of his second year. In the autumn of 1959 Coull took up an Assistant Lectureship and commenced doctoral research. His career path was mirrored by four others: E. Alistair Smith joined the academic staff in 1962 followed by John S. Smith in 1965 and Sandy Mather in 1967. Mike Wood, who graduated in 1968, was appointed to the staff in 1969 following a year away from Aberdeen studying for a taught postgraduate degree at the University of Glasgow. These five men went on to spend their entire careers at Aberdeen. Other appointments made in the mid to late 1960s formed the core of the Geography staff for the best part of four decades.

\section{St Mary's becomes Geography's exclusive preserve and construction of the first St Mary's extension}

Increased staff and student numbers created huge pressures on teaching and other Departmental space requirements during the 1960s. In The Orb, March 1964, O’Dell wrote 'There is tremendous pressure on our present limited accommodation, but we look forward to occupying the upper floors of St Mary's when Law and Psychology move into the new Taylor Building'. St Mary's became the exclusive domain of Geography in the Spring of 1964 (Figure 15). The complete occupation of the building was accompanied by the installation of state of the art facilities and equipment including: 
six new Grant Projectors, the new duplicating machine and ancillary equipment ... and a well-equipped room for research students. We also possess an ingenious filing system to hold 18,000 'two by two' colour transparencies .... Room has been provided for future expansion of the map collection, which now comprises over 75,000 sheets, and a specially equipped Map Control Room has been established (The Orb Vol. III, No. 4 March 1965).

St Mary's also became home to a closed circuit television system linking two lecture rooms, a feature which enabled the accommodation of 'the whole of the Ordinary and Science 1 class in the building at the same time'. The CCTV was hugely innovative; the new Head of Department, Ken Walton, wrote in 1967 'It would not be unfair to say that we are possibly among the leaders in the use of this teaching medium in the Geography Department. We have also experimented in the making of short films for teaching purposes and our fist gripping epic - 'The Use of Levelling Equipment' will have its premier in the near future (The Orb, March 1967).

As the 1960s progressed, more academic staff, many more undergraduate students, a growing postgraduate research community and a large technical, cartographic and administrative staff ${ }^{\mathrm{xix}}$ meant that the Geography department was bursting at the seams. Despite occupying the entirety of the former church building of St Mary's from 1964, there still was not enough space. A large extension was the solution. Work started during the Christmas vacation of session 1967-68 and the new building, which doubled the Department's floor space, was opened by Lord Tweedsmuir in 1968. The main entrance to St Mary's was relocated from the High Street to Elphinstone Road, where it remains today (see Figure 16). The ground floor of the extension housed workshops and specialist laboratories, the upper levels each contained a large, air conditioned lecture theatre and staff offices were located on the first and second floors, numerous enough to allow all the Geography staff to be housed in St Mary's. The 
former first floor lecture theatre in the old church part of St Mary's was reconfigured into a large Map Control and Store Room. The new laboratories included sediment analysis and photo-interpretation facilities (with new kit including a Kern PG-2 photogrammetric plotter) and the lecture theatres were fitted with CCTV and other state of the art visual aids.

\section{Tarradale House}

As noted in section 2.3, fieldwork was central to teaching and research in Geography from the earliest years of the Department and Tarradale House became an intrinsic part of this endeavour. Originally the home of the famous geologist Sir Roderick Impey Murchison (1792-1871), Tarradale House (Figure 17), ‘a modest mansion' on the north bank of the River Beauly near Muir of Ord, had passed into the ownership of Murchison's relative Miss Amy Yule who added a library tower and walled garden ${ }^{\mathrm{xx}}$. Following her death in 1916, it hosted numerous fieldtrips and study visits from Aberdeen University students and staff and those from other institutions. The property was subsequently run under the provisions of the Murchison of Taradale ${ }^{x x i}$ Memorial Trust Scheme as codified in 1936:

\section{The Murchison of Taradale Memorial Trust Scheme, 1936}

This Trust was founded under the Last Will and Testament and Codicils of Miss Amy Frances Yule of Taradale, and is regulated by a Scheme of Administration under the provisions of the Educational Endowments (Scotland) Acts, 1928 to 1935, approved by His Majesty in Council on 2nd February 1937. For the purpose of the Scheme, a governing body shall be constituted under the name of 'The Governors of the Murchison of Taradale Memorial Trust'. The Scheme provides inter alia that the governing body shall develop Taradale as a centre preferably for research into and the study of (a) the History, Language, Literature and Antiquities of the Highlands, and (b) The Natural Sciences, 
including Botany, Geography, Geology and Ornithology. The governing body is empowered to review the contents of the Library and to open Taradale to students for such period of the year as the trust funds permit. Before admitting any student, the governing body shall satisfy themselves that he is a genuine and meritorious student preferably of one or more of the subjects above described who could not from his own resources provide himself with opportunities for research or study similar to those available at Taradale. It shall be in the power of the governing body to fix the period for which each student is to be admitted and to make such charge as they may think fit towards defraying the costs of board and lodging of each student.

Further particulars may be had on application to the Clerk to the Governors, Mr. John Cameron, LL.B., Ph.D., 55 West Regent Street, Glasgow, C.2.

(Source: The Aberdeen University Calendar for 1943-44, Appendix A Funds for Students, pp. 4-5.)

The house was threatened with demolition in the late 1950s and Andrew O'Dell campaigned to save it and to transform it into a field centre for Aberdeen students. In 1961 Tarradale House and its library came under the ownership of Aberdeen University and the Geography Department undertook its management. As John Smith (undated, p. 19) recounts 'Together with his wife, Andrew by personal example and labour, enthusiastically led the campaign to transform Tarradale into a going field centre, leading work parties armed with oil laps and candles over long weekends to render the interior of the house habitable'. Smith also recorded that 'Much of the house renovation was carried out by volunteer work parties on a shoe-string budget' (ibid. p. 6). This effort was formally recognised by the University Court which minuted its appreciation for the rehabilitation efforts undertaken by students and others. The first field party went to Tarradale in March 1961. In March 1962 'The Year in the Department' article noted that 'an instructional period for normal fieldwork and survey' at Tarradale 'is planned as an integral part of the curriculum for our third year students were planned for 
academic session 1962-63' (The Orb March, 1962) and that bookings for the first half of the coming season were 'already heavy'. From then until the early years of the twenty-first century, Tarradale was to be synonymous with Aberdeen students and field work. The photograph of Tarradale reproduced in Figure 17 is undated but most likely was taken in the 1980s. Increasing operational costs were influential in the decision by the University to sell the property and in 2003 it was bought by an Aberdeen Geography alumnus ${ }^{x \times i i}$.

The Department suffered a huge loss in 1966 with the sudden and unexpected death of Andrew O'Dell. It was under O'Dell's leadership that the Department had grown and thrived in the two decades he had been Head of Department. O'Dell had also been hugely influential in spheres beyond St Mary's. University administrative activities listed in his obituary which appeared in the December 1967 issue of the Transactions of the Institute of British Geographers (unattributed but most likely to have been written by his Aberdeen Geography colleague and successor as Head of Department, Kenneth Walton), included Curator of the Library, member of the University Court and Dean of the Faculty of Science. He had also been very active in wider academic circles, editing the volume The North-East of Scotland published by the British Association for the Advancement of Science to mark its visit to Aberdeen in 1963, serving as an Assessor for Planning Appeals and sitting on Committees of the London Congress of the International Geographical Union. He was also a founder member, member of Council and a President-elect of the Institute of British Geographers. 


\section{Further growth and financial crisis: the 1970s and 1980s}

The 1970s was largely another decade of expansion for Geography at Aberdeen. Under the leadership of Ken Walton the staff complement continued to grow. Undergraduate numbers remained very large. The average number of Honours graduates in Geography per year in the 1960s was 31, in the 1970s the average cohort was 55 (see Figure 18). Continued expansion in student numbers promoted various innovations in teaching and learning in the late 1960s and 1970s. A Students' Committee was established in session 1967-68 to improve liaison and facilitate staff-student communication. Staff-Student consultative committees are now commonplace, but Geography at Aberdeen was ahead of the curve in formalising opportunities for academic staff and students to discuss and review the educational experience and wider departmental life. Other signs of a vibrant department are considered below. First, changes in the curriculum associated with wider philosophical debates within the discipline and a shift away from regional to a systematic Geography mark the late 1960s and early 1970s. Second, the late 1960s and early 1970 s were the years during which a sizable postgraduate community in Geography emerged. Thirdly, the place of research within the department became more prominent.

\section{Geography's changing philosophical landscape}

Undergraduate students at Aberdeen and elsewhere have, for many years, studied the history of and philosophical developments within Geography as a core element of their Honours programme. Aberdeen Geography undergraduates in the late 1960s and 1970s were taught during a period when major philosophical and organisational changes were taking place across the discipline, challenging and changing how geographical 
scholarship was undertaken and geographical education was delivered. The quantitative revolution, a desire to make Geography more 'scientific' and 'relevant', calls for human geographers to engage with behavioural and humanistic approaches and a shift from regional studies to systematic studies were all reflected in the evolution of the undergraduate curriculum and stimulated contributions from staff and students in The Orb.

The content of the Geography curriculum had been revised and updated regularly since the first Geography syllabus was introduced in 1920. However, a focus on largely atheoretical, descriptive regional geography from second year onwards remained until the late 1960s. Students sitting finals in academic session 1971-72 were the first to be examined under a new format whereby papers on systematic geography topics took precedence. There were now three Systematic Geography papers, a General Geography paper, a Regional Geography paper and two Special Subject papers. In addition students also completed a thesis and an assessment of practical work completed in class (full details of the revised degree structure is presented in Appendix 6). This change reflected the movement towards geographical enquiry being conducted within the context of specific sub-disciplinary areas. Staff increasingly identified themselves as experts in a particular sub-area of the discipline. By 1971 amongst the Aberdeen staff there were experts in, for example, historical geography, transport geography, economic geography, coastal geomorphology and glacial geomorphology: these specialisms were reflected in the range of Honours courses offered to students. Regional study remained an element of the curriculum, but it was no longer central to it.

Aberdeen staff and students were caught up in the maelstrom of philosophical developments and debates within Geography, in the classroom and in less formal spaces of learning including the pages of The Orb. Between 1970 and 1978 editorial 
introductions and contributed articles debated topics including the role of regional geography (Sugden, 1970; Robin, 1971) interdisciplinarity (Mathewson, 1971), perception studies and behavioural approaches (Butler, Cook, Kiddie, Menzies and Moir, 1971; Findlay, 1975), and radical geography and geographies of 'relevance' (Milne, 1978). In these contributions The Orb became what Philo (1998, p. 344) described as 'a 'semi-academic space', one entailing a hybridity of academic and student voices'.

\section{Postgraduate education}

By the early 1970s a research student community was well established in St Mary's; there were 18 research students in session 1972-73. Many doctoral graduates from the 1960s and 1970s went on to achieve senior positions in the academy in the UK and elsewhere. Taught postgraduate programmes, offered at Diploma or Masters levels, began to appear in British Universities in the late 1950s. Before this, postgraduate study was normally the exclusive preserve of research students, or study undertaken by graduates wishing to enter the teaching profession. One of the early taught postgraduate degrees (referred to as an 'instructional' course) introduced at the University of Aberdeen involved Geography as a key player. In session 1968-69 the first intake of students on the two-year MSc Rural and Regional Resources Planning (RRRP) commenced their studies. Geography acted as the coordinating department for the MSc and contributed courses alongside contributions from other departments across the University and from The Scott Sutherland School of Architecture of the then Robert Gordon's Institute of Technology. By session 1972-74 there were 14 students studying for the MSc RRRP and MSc student numbers remained buoyant for many years. The 
degree continued to be delivered, albeit not in the original format and from session 2002-3 under the name of MSc Sustainable Rural Development, until academic session 2010-11. A second taught postgraduate degree, MSc Environmental Remote Sensing, was launched in 1986-87. One of the earliest programmes of its type, this degree exploited the skills of Bobby Wright and Mike Wood in the first instance. Over time the degree was reoriented to incorporate Geographical Information Systems (GIS) and a name change in 2005-6 (to MSc Applied Geospatial Information Systems) reflected the increased focus on GIS in the degree. Now led by David Green, the MSc GIS continues to attract many home and international students.

\section{Research}

Since the early years of the department staff had pursued their own research interests, published their findings, and had engaged in conferences and other scientific meetings. Scholarly activity was deeply entrenched in departmental life. In the 1970s researchrelated activity increased, occupying an increasingly central role. There was a growing expectation, both locally on campus and in the wider British university environment that staff would undertake and publish findings from research - expectations formalised by the introduction, in 1986, of the Research Assessment Exercise (now known as the Research Excellence Framework). The Aberdeen Geography Department hosted the 1972 meeting of the Institute of British Geographers: this leading conference for academic geographers was attended by 450 delegates, more than twice the number expected.

Many 'Year in the Department' articles in The Orb listed details of staff research visits, fieldwork, conference and other scientific meeting contributions and significant 
publications. Domestic and international research undertaken in the first half of the 1970s included:

1970: Pat Hamilton and Chalmers Clapperton both undertook fieldwork in the Peruvian Andes; David Sugden undertook work in the Polish Carpathains 1970 and 1971: Jimmy Coull undertook research on fisheries in Norway and Russia

1971: Allan Hill undertook research in Beirut in 1971; Roy Mellor examined social geography problems in the Rhur, (West) Germany

1972: Alistair Smith continued his programme of comparative Scandinavian Scottish research investigating rural problems; Eric Naylor conducted research with farmers in Brittany, France; Chalmers Clapperton visited a newly formed volcano, Eldfell, on the island of Heimaey, Iceland.

1974: Chalmers Clapperton made 4 visits to Iceland to study different phases of the volcanic eruption at Heimaey; Keith Chapman undertook research visits to Norway and the Netherlands in association with his work on North Sea Oil developments 1975: Jeffrey Stone pursued his interests in historical cartography in Zambia; Brian Clark undertook research in Iran; Chalmers Clapperton undertook further work in the Andes

During the late 1960s and 1970s a number of large-scale research projects conducted by members of the Geography department were supported by external funding won from public sector bodies and the UK research councils. For example, Chalmers Clapperton and David Sugden secured successive tranches of funding, including from the Natural Environment Research Council, to support a programme of work investigating the Quaternary geomorphology of the Antarctic and Sub-Antarctic. Outputs included research papers (cf. Sugden \& Clapperton, 1977 and 1980; Clapperton \& Sugden, 1982 and 1988; Clapperton et al., 1989) and maps that were jointly printed and copyrighted by the British Antarctic Survey and the University of Aberdeen. In 1971 John Farrington conducted a survey of Aberdeen's air services for the North East Scotland Development Authority and British European Airways (BEA). Bill Ritchie and 
Sandy Mather undertook a series of beach surveys, reporting on a county basis work funded by the Countryside Commission. The culmination of their seven year programme of research was the 1977 publication The Beaches of the Highlands and Islands of Scotland (Ritchie \& Mather, 1977). Commencing in 1970, John Smith was funded by the Highlands and Islands Development Board to undertake a long term study of the impact of the development in the Invergordon area on the physical environment. Findings from these, and other, research projects were published as O'Dell Memorial Monographs, a series of research publications that many members of the Geography staff contributed to between 1968 and $2000^{\text {xxiii. }}$

External funding also supported the establishment, in 1973, of the first research centre associated with Geography at Aberdeen, the Project Appraisal for Development Control (P.A.D.C.) Environmental Impact Assessment and Planning Research Group ${ }^{x \times i v}$. The first project undertaken by P.A.D.C. was funded by the Scottish Development Department and the Department of the Environment and led to the publication of the substantive report DoE Research Report no. 13 Assessment of Major Industrial Applications - A Manual. The manual had considerable impact within the UK; the appraisal methods it set out for evaluating the potential consequences of development proposals were used by many local authorities throughout the UK. Under the direction of Brian Clark, and assisted by Keith Chapman, the P.A.D.C. unit developed a strong reputation in the UK and overseas, going on to undertake UK-focused work funded by the Natural Environment Research Council and various UK government departments, and international work funded by the World Health Organisation and the United Nations. In 1983 the P.A.D.C unit metamorphosed into a University spin out company, the Centre for Environmental Management and Planning. 


\section{Continued growth in student numbers and more building work}

In the early 1970s a second UK-wide University expansion programme was initiated, with Aberdeen's student population expected to increase by an additional 3,000 students, bringing it to a total of approximately 8,000. Ken Walton noted in The Orb (Vol. 5. No. 4, 1973) that Geography was expected to get a proportional share of this increase. Unfortunately the numbers studying $1^{\text {st }}$ and $2^{\text {nd }}$ year geography are not recorded in The Aberdeen University Calendar after 1969-70, but references to the size of some classes, and to the number of Honours graduates continued to be made in the annual 'Year in the Department' articles which allow the effect of this sector-wide expansion on Geography's student population to be illustrated (Figure 18). Once again space in St Mary's was at a premium. The 'St Mary's Mouse' recalled, in the 1981 issue of The Orb (Vol. 7 No. 3), that there was talk in the early 1970s of the University constructing a large building - 'some said a skyscraper' (p. 6) - on Lord Hay’s Road with Geography and related departments to be the occupants. This was 'in anticipation of the student population rising to 12,000 ', a number that was not forthcoming due to 'a reappraisal downwards of projected University numbers' (ibid.) as a result of the ArabIsraeli War of 1973 and the associated OPEC oil crisis which rocked international markets. Instead of relocating to a new site, talks began in 1976-77 about an expansion on the existing St Mary's site. Plans for a second extension to St Mary's, utilising space hitherto used as a car park, were developed. Ken Walton was very influential in this process but his unexpected death in 1979 meant that he never saw the finished building.

Building works for the second extension to St Mary's commenced in the winter of 1979-80 (see images in Figure 19). This development effectively doubled the floor space of St Mary's. It contained a laboratory suite (known for many years as the 'Red Corridor') housing specialist facilities for physical geography, palynology and 
archaeological research, photogrammetry, cartography, remote sensing, ample storage space, a wet area and a loading bay. Numerous staff offices and teaching rooms of various sizes were also contained within the new building. Of significance to Geography's development, the construction of the second St Mary's extension is also a significant event in the University's recent history as it is a physical marker of the financial crisis that beset the institution in the 1980s. Writing in The Orb (Vol. 7 No. 3 1981) the 'St Mary's Mouse' reported that the second extension was very nearly not built: 'permission to undertake the work was received only five days before a final clamp down on all further new buildings was made by the [UK-wide] University Grants Committee' (ibid. p. 6).

\section{Financial crisis}

Throughout the 1970s the department faced some financial challenges, mirroring the swings in the UK economy that affected the amount of funding made available to the Higher Education sector. The impact of these challenges was, however, comparatively minor compared to the impacts the Department felt in the 1980s as a result of the swingeing cuts imposed on the University of Aberdeen by the University Grants Committee.

The text that follows was published in the Newsletter of the University of Aberdeen (a publication that was issued to all staff at regular points though the year) in February 1982. It is from a joint statement by Grampian Regional Council, the City of Aberdeen District Council and the University of Aberdeen issued in response to the financial cuts: 
Grampian Regional Council and the City of Aberdeen District Council, concerned at the effect on the communities they represent of the scale of reduction in Government financial support for the University of Aberdeen, join with the University itself in pressing the Government to reconsider the extent and timing of the cuts.

It is not the purpose of these representations to criticise or seek a review of the general policy of which the cuts affecting the University of Aberdeen are part, though the Councils cannot view with complacency a policy that will reduce by one in seven the opportunities of young people to receive a University education. What concerns us here is the particularly severe pruning proposed for a University set in the heart of the major economic growth area of the United Kingdom economy, the only University in the North of Scotland and seventy miles away from its nearest neighbouring University.

(Newsletter Vol 1, No 2 Feb 1982, p. 1-2)

The cuts had serious repercussions for the Geography Department. The then Head of Department, Roy Mellor, described the period 1981-82 as 'without question the blackest year in the history of the Department' (The Orb Vol 7, Number 4, p. 1) and went on to describe 'radical economies' in staffing. A further round of cuts was imposed in 1986. Devine (1999, p. 604) made reference to this, writing that 'The 500 year old University of Aberdeen endured a savage round of cuts in 1986 which cost more than 200 redundancies and closed six arts faculty departments'. Despite an indication from University senior management in 1981 that Geography would have to lose seven academic staff, losses were not quite so severe. Two staff moved onto fractional contracts, David Sugden's post was not filled when he left Aberdeen, and Roy Mellor's position remained empty after his retirement in 1986. Plans to launch an Archaeology department as an extension of archaeologically-focused teaching already delivered within Geography were abandoned and Ian Ralston transferred to the University to Edinburgh in 1985. Losses were also experienced in the Department's complement of technical and administrative staff, personnel whose contribution, as 
Gemmell and Chapman recall in their contribution to this Special Issue, had been central to many research and teaching activities since the 1960s. Only one new appointment was made in the 1980s when David Green was appointed (in academic session 1988-89) to provide additional capacity to deliver the MSc Environmental Remote Sensing and other related teaching utilising new computing technologies.

\section{The recent past}

The landscape of Higher Education in the UK continued to evolve and change in the 1990s and early 2000s. Regular external research assessment has become an increasingly important feature, placing more emphasis upon high quality research as a key activity amongst the portfolio of activities undertaken by academic staff on 'teaching and research' contracts. The number of young adults entering Higher Education grew in the 1990s, culminating in New Labour's electoral pledge in the run up to the 2001 general election, that they would set a target of $50 \%$ of young adults to enter Higher Education within a decade. Many Universities have undergone internal restructuring, for example, combining groupings of Departments into academic Schools and replacing Faculties with Colleges. The introduction of student tuition fees south of the border has had an impact on Higher Education in Scotland and elsewhere in the UK. These national shifts have all had an impact on the University of Aberdeen and the Department of Geography. At the same time undergraduate and taught postgraduate programmes in Geography have continued to evolve and there has been near constant churn in the complement of staff who comprise the 'Department' over the past 30 years. 


\section{The Research Assessment Exercise/Research Excellence Framework and its impact on the Department's academic staff profile}

The first formal attempts to evaluate research performance across the University sector, the Research Assessment Exercise (RAE), came in 1986. Since then this much debated and critiqued process has come to dominate many aspects of academic life, not least because research 'scores' inform the allocation of 'quality weighted research funding' each Higher Education Institution receives each year from the national funding councils (in Scotland, the Scottish Higher Education Funding Council). RAEs took place in 1986, 1989, 1993, 1996, 2001 and 2008. The first Research Excellence Framework was held in 2016, the next takes place in 2021. Geography at Aberdeen scored very well in the 1989 RAE, but a disappointingly lower score was achieved in 1993 for various reasons (as recounted by Keith Chapman, Head of Department at the time, elsewhere in this Special Issue). Retirals throughout the 1990 s and into the 2000 s of staff who were beyond their 'research peak' or whose professional activities had focused on teaching efforts rather than research meant that the number of 'research inactive' academic staff diminished considerably. New appointees with research potential or a demonstrable research track record joined the department (seven new appointments were made between 1993 and 1995) and recruitment efforts were targeted towards aligning the research specialisms of new staff appointees with the development of new, or bolstering of, existing clusters of staff with cognate research interests. The numbers of 'RAE-able' staff increased as a direct result of this recruitment strategy and RAE performance (and thus departmental financial resource associated with the research quality grant) improved. In 2014 an institutional decision was taken, in line with comparable decisions made in some other Universities, to allocate Geography staff to separate Units of Assessment (UoA) in the first Research Excellence Framework assessment. Human 
geography staff were submitted to UoA 16 Architecture, Built Environment and Planning, some physical geography staff to UoA 17 Geography, Environmental Studies and Archaeology and the remaining physical geography staff to UoA 7 Earth Systems and Environmental Sciences. All three submissions did well but an official 'Aberdeen Geography' presence was missing from the results. Any long-term effects of this absence, such as an impact on the visibility of the discipline at Aberdeen both internally and externally, remain to be seen.

\section{Institutional restructuring and academic staffing}

In the past couple of decades there has been quite a fashion for institutional restructuring within UK Higher Education. In many Universities Faculties have been replaced by Colleges and previously autonomous, discipline-based Departments have been combined to create multi-disciplinary academic Schools. In some institutions such restructuring has reduced the visibility of Geography as an organisational unit and named degree programme and compromised academics' personal sense of being 'a geographer' (cf. Hall et al., 2015). At Aberdeen a Faculty-based organisational structure was replaced by a three College structure in 2002. Geography had been managed within the Faculty of Social Science and then became part of the new College of Physical Sciences. Around the same time academic Schools were created and Geography became a discipline within the new School of Geoscience. The move to Schools created a Head of Discipline role, a much diminished version of the former Head of Department role (e.g. Heads of Discipline no longer controlled the budget for their unit). Sandy Mather was the last Head of Department in the traditional sense. His successors, John Farrington, Jon Shaw, Helmut Geist, Tim Mighall and Doug Mair, were never able to 
shape Departmental life and future strategy in the way their predecessors such as Andrew O'Dell or Ken Walton had done.

Since the year 2000, 32 individuals (including the authors of this contribution) have joined the Geography academic staff and 40 have left. This level of churn, whilst not unusual in contemporary British Higher Education, is in marked contrast to the relative stability ${ }^{\mathrm{xx}}$ of the staff complement in earlier periods of the Department's history. A number of staff departures were due to retirements (including those of long standing colleagues Pat Hamilton, John Farrington, Al Gemmell, John Loder, Lawrie McLean, Mike Wood and Bobby Wight). John Smith and Sandy Mather both died in post in 2004 and 2006 respectively. Other staff moved on to new academic positions with the move often being to a more senior post. In the 1990s and 2000s most staff departures led to like-for-like replacement posts being advertised. In 2004, as a result of an institutional decision to 'realign' the Department of Land Economy, five academic staff - Lorna Philip, Aileen Stockdale, Adam Barker, Steve Tiesdell and Douglas MacMillan - were moved into Geography. They brought with them undergraduate programmes accredited by the Royal Town Planning Institute and the Royal Institution of Chartered Surveyors and a well-established taught postgraduate programme, the Master of Land Economy (Rural Surveying). A few years later efforts to bolster Town Planning education at Aberdeen included the University making a number of new appointments within what quickly became a Planning group, administratively separate to Geography (although both groupings fell within the School of Geoscience). Student numbers on the professionally accredited undergraduate programmes continued to decline and the Planning Group and the undergraduate degree programmes it delivered were closed in 2013. The Master of Land Economy degree programme was retained and today it is one of the three taught postgraduate programmes offered by Geography. 
Efforts to bolster staffing of the Planning Group were, at the time, thought to have been at the expense of replacing departing geographers with new members of Geography staff. A long term impact of this has been a shrinking Geography department in terms of staff numbers, but although diminished in number, Geography has retained a strong research profile, healthy research postgraduate numbers, responsibility for three taught postgraduate degree programmes and, as described below, continues to deliver a very popular undergraduate degree programme.

\section{Degrees in Geography and the student population}

The Royal Geographical Society recently launched an accreditation programme for Geography degrees and Aberdeen's Geography programmes were amongst the first to receive endorsement in the summer of 2018. The Geography undergraduate programme was thoroughly reviewed eight years ago and the new structure introduced as a result of the review remains in place today, although the content of individual courses has, of course, been regularly reviewed, updated and modified. Two first year courses, Global Worlds Global Challenges in the first half session, Global Worlds Local Challenges in the second half session, and five second year courses are offered. First year Geography in particular is a very popular 'outside' subject for undergraduates with a degree intention in a subject other than Geography. A few years ago, numbers on both first year Geography courses exceeded 300. Staff resources were stretched to deliver the smallgroup teaching elements of both courses. Numbers have fallen back to more manageable levels in the last couple of years and are now closer to the first year numbers typical for the discipline in the 1970s. Students intending to progress to Honours Geography must take, and pass, Skills and Techniques in Geography in their 
second year, a course that includes a residential fieldtrip. A strong sense of belonging to the Department and to a specific cohort of students is normally developed on the second year fieldtrip where current destinations include the Cairngorms and Stirling. The Junior Honours year focuses on the development of conceptual and practical applications of geographical knowledge, including training in research skills, and the history and philosophy of the discipline. Optional overseas field trips are available which require students to design, undertake and write up research projects undertaken in small groups. Students who go to the Italian Alps focus on physical geography and those going to Boston, USA are more interested in human geography. Senior Honours students have an opportunity to take specialist Honours option courses: some combine human and physical geography options, others elect to specialise in one or other side of the discipline. The Honours courses reflect research strengths of the current staff and include Environmental Hydrology, Glaciology, Environmental Change, Rural Geographies, Transport Geography and Digital Geographies. Senior Honours student numbers, based on the number of Geography dissertations ${ }^{x \times v i}$, grew throughout the 1990s, a reflection of the UK-wide increase in the number of University students. Senior Honours Geography numbers peaked in session 1997-98 when 95 dissertations were completed. In the past 10 years the Honours cohorts have not been so large, but graduating classes have been in the region of 60-65 students over the past decade.

Most UK Universities have sought to expand their taught postgraduate provision over the past few decades and Aberdeen has been no exception. As noted earlier, Geography was a key player in the establishment of one of the first taught postgraduate degrees to be offered at the University of Aberdeen. The MSc Rural and Regional Resource Planning (latterly MSc Sustainable Rural Development) attracted students from across the UK, Europe and further afield and many graduates now occupy senior 
positions in the public, private and voluntary sectors. In 2016 a successor to the MSc SRD was launched, an MSc Environmental Partnership Management under the leadership of Tavis Potts. The Master of Land Economy (Rural Surveying) degree continues to attract students for whom completion of a degree accredited by a professional body allows them to pursue a career in rural land and business management. The MLE is currently led by the newest appointment to the Geography academic staff, Katrin Prager. The MSc Geographical Information Systems, led by David Green, continues to be a very popular degree, equipping students with the skills required to apply geospatial technologies in commercial, industrial and government settings. In academic session 2018-19 there were about 50 on-campus taught postgraduate students taking one of these three programmes and more registered to complete, as distance-learning students, individual elements of the MSc GIS programme.

The Department continues to host a sizeable postgraduate research student community. Membership of the Scottish Graduate School of Social Science and its ESRC Doctoral Training Partnership has offered training and professional development opportunities to human geography research students since 2010 . Now embedded within this pan-Scotland collaboration is the work of the Advanced Research Training in Human Geography consortium (often referred to as the 'Kindrogan' consortium after the field centre which hosted annul residential training events for many years; see Gwanzura-Ottemoeller et al. (2005) for further details). With contributions from staff based in all Scottish University Geography Departments, the consortium has trained successive cohorts of students for more than a quarter of a century. Twenty-first century research students in Geography, especially those in physical geography, have also benefited from the SAGES (Scottish Alliance for Geosciences, Environment and 
Society; see next section) Graduate School which has either funded or assisted the research careers of a substantial number of $\mathrm{PhD}$ students supervised from or jointly with Aberdeen. The most recent opportunity for Aberdeen's geographical doctoral community is the award in 2018 of a NERC Doctoral Training Centre, Quadrat, that will support postgraduate research in Geosciences and Biological Sciences at the Universities of Aberdeen and Queen's Belfast. This will provide the funds for 20 full studentships for every year of the scheme (2019-24) orientated towards the themes of biodiversity, earth systems and environmental management, allowing for an integration of both theoretical and applied multi-disciplinary projects.

\section{Final words}

The contemporary University is a site of teaching and research. The presence of both activities in the history of the Geography Department have been chronicled in this account. Contributions that follow in the Special Issue reflect on past and present research strengths. These are the result of investigative efforts by academic staff, postdoctoral research fellows, research assistants, research postgraduate students and honorary staff. Aligned with these records it is useful to draw attention to some major highlights from the recent past that illustrate research and educational strengths.

The first million pound grant was obtained by Kevin Edwards as Principal Investigator (PI) in 2002 when a $£ 1.25^{\text {xxvii }}$ million Programme Award was made by the Leverhulme Trust for the study Landscapes circum-Landnám: Viking settlement in the North Atlantic and its human and ecological consequences. This was succeeded in 2007 by a follow-up grant (Footprints on the edge of Thule: landscapes of Norse-indigenous interaction) of $£ 1$ million. In 2009, a UK research council consortium grant (EPSRC, 
with $\mathrm{AHRC}, \mathrm{ESRC}$ and MRC ${ }^{\mathrm{xxviii}}$ ) under the Digital Economy programme for $£ 11.8$ million was awarded to the University for a dot.rural Digital Economy Research Hub. At the time of award this was the highest value research grant that University of Aberdeen academics had ever secured. Geography played a major part in dot.rural (initially with John Farrington, latterly with John Nelson as co-PI) along with the Department of Computing Science (co-PI Peter Edwards). In 2013, Doerthe Tetzlaff received a $€ 1.5$ million award from the European Research Council for $\mathrm{VeWa}$ : Vegetation Effects on Water Flow in High-Latitude Ecosystems. The SAGES alliance (phase 1, 2007-14; phase 2, 2015-20) is a pan-Scottish Government-funded pooling initiative $^{\mathrm{xxix}}$ which has provided more than $£ 7.1$ million of Scottish Government support along with a much larger amount of leveraged funding. SAGES is a multi-disciplinary alliance at the forefront of earth and environmental science research and education and many members of the Geography staff and research students at Aberdeen have participated in its evolving themes. ${ }^{\mathrm{x} x}$ Income is not, of course, a prerequisite for research excellence and many studentships and project-appropriate grants from funders including research councils, charitable organisations and government departments represent the more conventional 'bread and butter' of research facilitation.

Since the Department's inception, staff have combined their 'day job' at the University with wider professional and scholarly activities. Journal editorships and editorial board memberships, article reviewing and membership of research council grant selection committees have and are to this day common. Membership of professional bodies, roles on committees thereof, and engagement with civic society (which in an era of impact and knowledge exchange is increasingly important) take staff into scholarly and public realms beyond the Old Aberdeen campus. The increased turnover in academic staff over the past two decades was noted above; this, and periods 
of retrenchment depleting the staff complement have not just been a feature of academic life at the University of Aberdeen. The departure of colleagues to pastures new is, at one level, met with sorrow but we have rejoiced with colleagues when they have taken up posts elsewhere, especially upon promotion. Similarly, we have been delighted when various distinctions have been bestowed upon current and recent members of the Department (Appendix 7).

An ethos of teaching excellence and pastoral concern has always characterised the work of the Department of Geography at Aberdeen, even though this may have become less apparent over time as the constraints imposed by research rankings and institutional pressures suffuse the University of Aberdeen as it does all research-led organisations. Nevertheless, the Department continues to perform highly in terms of national student satisfaction and graduate prospect surveys. ${ }^{x \times i}$ Teaching, education, pastoral care for students and staff, research and scholarship represent inter-related strands which need to be balanced and cherished - hopefully in the context of Geography's next 100 years.

\section{Acknowledgements}

Our sincere thanks are offered to John and Julie McFarlane, grandson and grand-daughter in law of the first member of the Geography staff, John McFarlane, for kindly providing access to materials held in their family archive. Staff in Special Collections at the University of Aberdeen's Sir Duncan Rice Library are thanked for their assistance in locating a variety of materials that have proved invaluable sources for this paper, and for their interest in our endeavours to produce a history of Geography at Aberdeen. 


\section{References}

Aberdeen University Review (1960) Geography in Aberdeen University Review

'Fusion' Centenary Number (1960) 38, 4 No. 123 September 1960, 386-387.

Anderson, R. D. (1988) The student community at Aberdeen 1860 - 1939.

Quincentennial Studies in the history of the University of Aberdeen (Aberdeen:

Aberdeen University Press).

Anonymous (1967) Obituary: Andrew Charles O’Dell, Transactions of the Institute of

British Geographers, 42, pp. 189-192

Bridges R. C. (1985) The foundation and early years of the Aberdeen Centre of the

Royal Scottish Geographical Society, Scottish Geographical Magazine, 101(2),

$77-84$.

Campbell, C., Keighren, I., Morris, N., Penrose, J., Short, N., Withers, C. W. J. \&

Woodhouse, I. (2008) Geography’s Hundred: A Special Issue to Mark the

Centenary of Geography at the University of Edinburgh, 1908-2008 Guest

Editorial, Scottish Geographical Journal, 124 (2-3), pp. 101-102.

Carter, J. J. \& McLaren, C. A. (1994) Crown and Gown 1495-1995. An illustrated history of the University of Aberdeen Aberdeen University Press, Aberdeen

Clapperton, C. M. \& Sugden, D. E. (1982) Late quaternary glacial history of George VI

Sound area, West Antarctica, Quaternary Research, 18 (3), pp. 243-267.

Clapperton, C. M., Sugden, D. E. (1988) Holocene glacier fluctuations in South

America and Antarctica, Quaternary Science Reviews, 7 (2), pp. 185-190

Clapperton, C. M., Sugden, D. E., Birnie, J. \& Wilson, M. J. (1989) Late-glacial and

Holocene glacier fluctuations and environmental change on South Georgia,

Southern Ocean, Quaternary Research, 31 (2), pp. 210-228.

Devine, T. (1999) A history of the Scottish nation (Harmondsworth: Penguin).

Findlay, A. \& Werritty, A. (2010) Putting geography in its place, Scottish Geographical Journal, 126 (4), pp. 215-230.

Fisher, W. B. (1952) The Aberdeen university expedition to Cyrenaica, 1951 Part I, Scottish Geographical Magazine, 68(2), pp. 57-63.

Fisher, W. B., Fraser, I. R. \& Ross, D. W. (1953) The Aberdeen university expedition to Cyrenaica, 1951 Part III, Scottish Geographical Magazine, 69(1), pp. 22-32. 
Freeman T. W. O (1984) The Manchester Geographical Society 1884 - 1984, The Manchester Geographer, 5, 1984, pp. 1-12.

Geography in British Universities (1905) The Geographical Teacher 3(2) September 1905 pp. 88-94 available at www.jstor.org/stable/40556213.

Gimingham, C. H. (1955) A note on water-table, sand movement and plant distribution in a North African oasis, Journal of Ecology, 43(1) pp. 22-25.

Gimingham, C. H. \& Walton, K. (1954) Environment and the structure of scrub communities on the limestone plateaux of Northern Cyrenaica, Journal of Ecology, 42, p. 505-520.

Gosme, C (2000) The Naval Intelligence Geographical Handbook Series (Great-Britain, 1941-46): a description and a call for comment, Cybergeo: European Journal of Geography [En ligne], Epistémologie, Histoire de la Géographie, Didactique, document 137, mis en ligne le 26 juin 2000, consulté le 30 août 2018. URL: http://journals.openedition.org/cybergeo/4460; DOI 10.4000/cybergeo.4460

Gwanzura-Ottemoeller, F., Hopkins, P., Lorimer, H. N. \& Philip, L. J. (2005) Advanced Research Training in Human Geography: the Scottish experience, Journal of Geography in Higher Education, 29(2), pp. 279-292.

Hall, T., Toms, P., McGuiness, M., Parker, C. \& Robert, N. (2015) Where's the Geography department? The changing administrative place of Geography in UK higher education, Area 47(1), pp. 56-64.

Hewitt, R. (2011) Map of a Nation. A biography of the Ordnance Survey (London: Granta Publications).

Kirk, W. (1986) The high road from Manchester to Aberdeen in the immediate post-war years in W. Ritchie, J. C. Stone \& A. S. Mather (editors) Essays for Professor R.E.H. Mellor pp. 1-6, Department of Geography, University of Aberdeen.

Lorimer, H. \& Philo, C. (2009) Disorderly archives and orderly accounts: reflections on the occasion of Glasgow's Geographical Centenary, Scottish Geographical Journal, 125 (3-4), 227-255.

Lorimer, H. \& Spedding, N. (2002) Excavating geography's hidden spaces, Area 34(3), pp. 294-302.

McFarlane, J. (1920) Geography and the Reconstruction of Europe, Nature September 16, pp. 92-96.

McFarlane, J. (1915) Economic Geography (New York: The MacMillan Company). 
NSA (1845) The New Statistical Account of Scotland (1845) Volume XII Aberdeen Account of the University and King's College of Aberdeen. https://www.electricscotland.com/history/statistical/kings.htm

O’Dell, A. C. O. The Year In the Department, The Orb Vol.1., No. 2, May, 1950 O’Dell, A. C. O. (1959a) Excavations at St. Ninan's Isle, Scottish Geographical Magazine, 75, pp. 41-43.

O’Dell, A. C. O. (1959b) The St. Ninian's Isle Silver Hoard, Antiquity, 33, pp. 241-68.

O’Dell, A. C. O. (1959c) Problems of the St. Ninian's Hoard, Aberdeen University Review, 38, pp. 15-18.

O’Dell, A. C. O. (1959d) The St. Ninian's Isle Hoard, The Geographical Magazine, 32, pp. $1-12$.

O’Dell, A. C. O. (1953) Obituary: John McFarlane, The Geographical Journal, 119(2). p. 250.

Philo, C. (1998) Reading Drumlin: academic geography and a student geographical magazine, Progress in Human Geography, 22(3), pp. 344-367.

Philo, C., Lorimer, H. \& Hoey, T. (2009) Special Issue: Glasgow Geography Centenary Guest Editorial, Scottish Geographical Journal, 125 (3-4), pp. 221-226.

Ritchie, W. \& Mather, A. S. (1977) The beaches of the Highlands and Islands of Scotland, Commissioned by the Countryside Commission for Scotland 1977. Reprinted 2005 by Scottish Natural Heritage as Commissioned Report no, 048.

Russell, J. L. (1974) Cosmological teaching in the seventeenth-century Scottish Universities, Journal of the History of Astronomy, 5 (1), pp. 122-132, 5 (2), $145-154$.

Shepherd, C. (1987) The Arts Curriculum at Aberdeen at the beginning of the Eighteenth Century, in J. J. Carter \& J. H. Pittock (eds) Aberdeen and the Enlightenment (Aberdeen: Aberdeen University Press) pp. 146-154.

Smith, J. S. (undated) A Guide to Tarradale House, $2^{\text {nd }}$ edition, Department of Geography, University of Aberdeen.

Sugden, D. E. \& Clapperton, C. M. (1977) The maximum ice extent on island groups in the Scotia sea, Antarctica, Quaternary Research, 7 (2), pp. 268-282.

Sugden, D. E. \& Clapperton, C. M. (1980) West Antarctic ice sheet fluctuations in the Antarctic Peninsula area, Nature, 286 (5771), pp. 378-381. 
Walton, K. (1952) The Aberdeen university expedition to Cyrenaica, 1951 Part II: The oasis of Jalo, Scottish Geographical Magazine, 68(3), pp. 110-119.

Withers, C. W. J. (2001) Geography, Science and National Identify. Scotland since 1520, Cambridge Studies in Historical Geography 33 (Cambridge: Cambridge University Press).

Withers, C. W. J. (2008) Edinburgh's Geographical Centenary - but an Intellectual and a Departmental history? Scottish Geographical Journal, 124 (2-3), pp. 103-116.

Withers, C. W. J. \& Mayhew, R. J. (2002) Rethinking 'disciplinary' history: geography in British Universities, c.1580-1887, Transactions of the Institute of British Geographers, New Series 27(1), pp. 11-29.

Wood, P. (1993) The Aberdeen Enlightenment: the arts curriculum in the eighteenth century, Quincentenial Studies in the History of the University of Aberdeen (Aberdeen: Aberdeen University Press).

Publications of the University of Aberdeen available for consultation in the Sir Duncan Rice Library Special Collections

The Aberdeen University Calendar

Aberdeen University Review

Newsletter of the University of Aberdeen 
Table 1. Teachers of Geography at King's College and Marischal College before 1887

\begin{tabular}{|c|c|c|c|}
\hline & $\begin{array}{l}\text { Name of individual and their } \\
\text { professorial subject }\end{array}$ & $\begin{array}{l}\text { Nature of their geographical } \\
\text { teaching }\end{array}$ & $\begin{array}{l}\text { Dates of teaching } \\
\text { geography } \\
\text { ('?' is inferred) }\end{array}$ \\
\hline \multirow{4}{*}{$\begin{array}{l}\text { King's } \\
\text { College }\end{array}$} & $\begin{array}{l}\text { William Black, regent (later sub- } \\
\text { principal) }\end{array}$ & Geography and cosmography & $1692-1693$ \\
\hline & George Skene, regent & Geographical propositions & $1701-1704$ \\
\hline & Thomas Reid, regent, moral philosophy & $\begin{array}{l}\text { Lecture programme on 'the } \\
\text { elements of geography' }\end{array}$ & $1752-1753$ \\
\hline & Thomas Gordon, humanity & Geography of the antients & 1761 \\
\hline \multirow{6}{*}{$\begin{array}{l}\text { Marischal } \\
\text { College }\end{array}$} & Matthew Mackaile, medicine & $\begin{array}{l}\text { Geography as part of natural } \\
\text { philosophy }\end{array}$ & $? 1717-1773$ \\
\hline & John Stewart, mathematics & $\begin{array}{l}\text { Geography, as part of a } \\
\text { mathematics course taught to } \\
\text { first year students }\end{array}$ & $? 1727,1748-1763$ \\
\hline & Thomas Blackwell Jnr, Greek & 'Ancient geography' & 1753 \\
\hline & James Beattie, natural history & Geography and civil history & 1787 \\
\hline & $\begin{array}{l}\text { Robert Hamilton, natural philosophy } \\
\text { and mathematics }\end{array}$ & $\begin{array}{l}\text { Principles of geography, the } \\
\text { use of globes }\end{array}$ & $1779-1829$ \\
\hline & $\begin{array}{l}\text { James Davidson, civil and natural } \\
\text { history }\end{array}$ & Natural geography & 1837 \\
\hline
\end{tabular}

Adapted from Table II in Withers and Mayhew, (2002, p18), including the addition of information in Wood (1993) 
Figure 1. King's College Aberdeen, around 1640

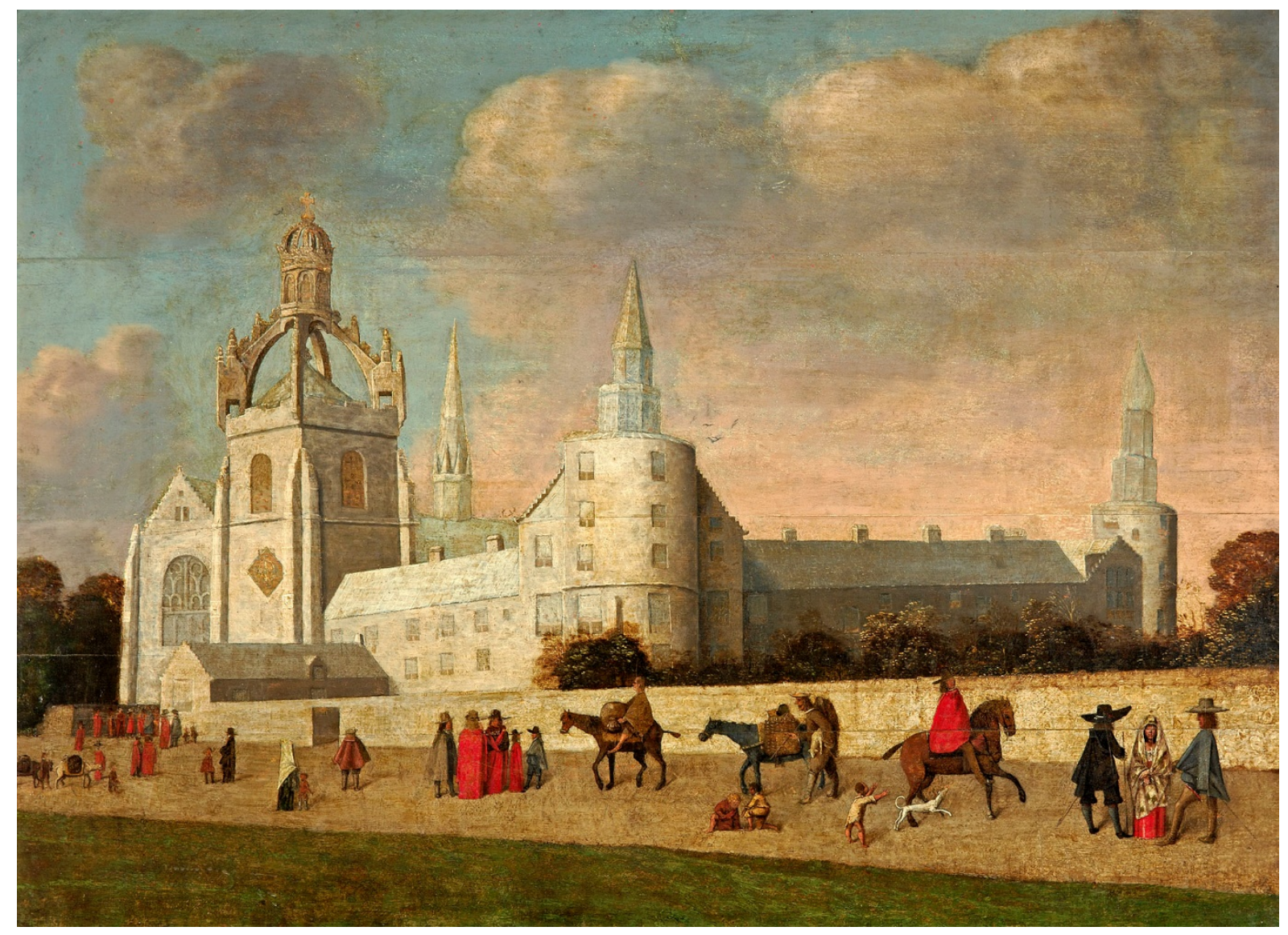

Source: University of Aberdeen Museum and Collections Human Culture Collection, catalogue number ABDUA 30012. Reproduced with the permission of the University of Aberdeen.

King's College as originally constructed, depicted by an anonymous artist around 1660 . This oil painting is the earliest surviving view of King's College. The form of the crown tower reflects its rebuilding in 1634 after storm damage. The existence of the pyramidal roof under the crown dates the work to pre-1658 before repairs to the chapel in 1658 removed the pyramid and replaced it with a flat roof. The iconic crown tower is widely used as an image to represent the University of Aberdeen. The figures clad in red, including those clustered around the main entrance to the college to the left of the painting, are wearing the red toga (gown) of undergraduate students. 
Figure 2. James Gordon's view of King's College from the south-west, 1661

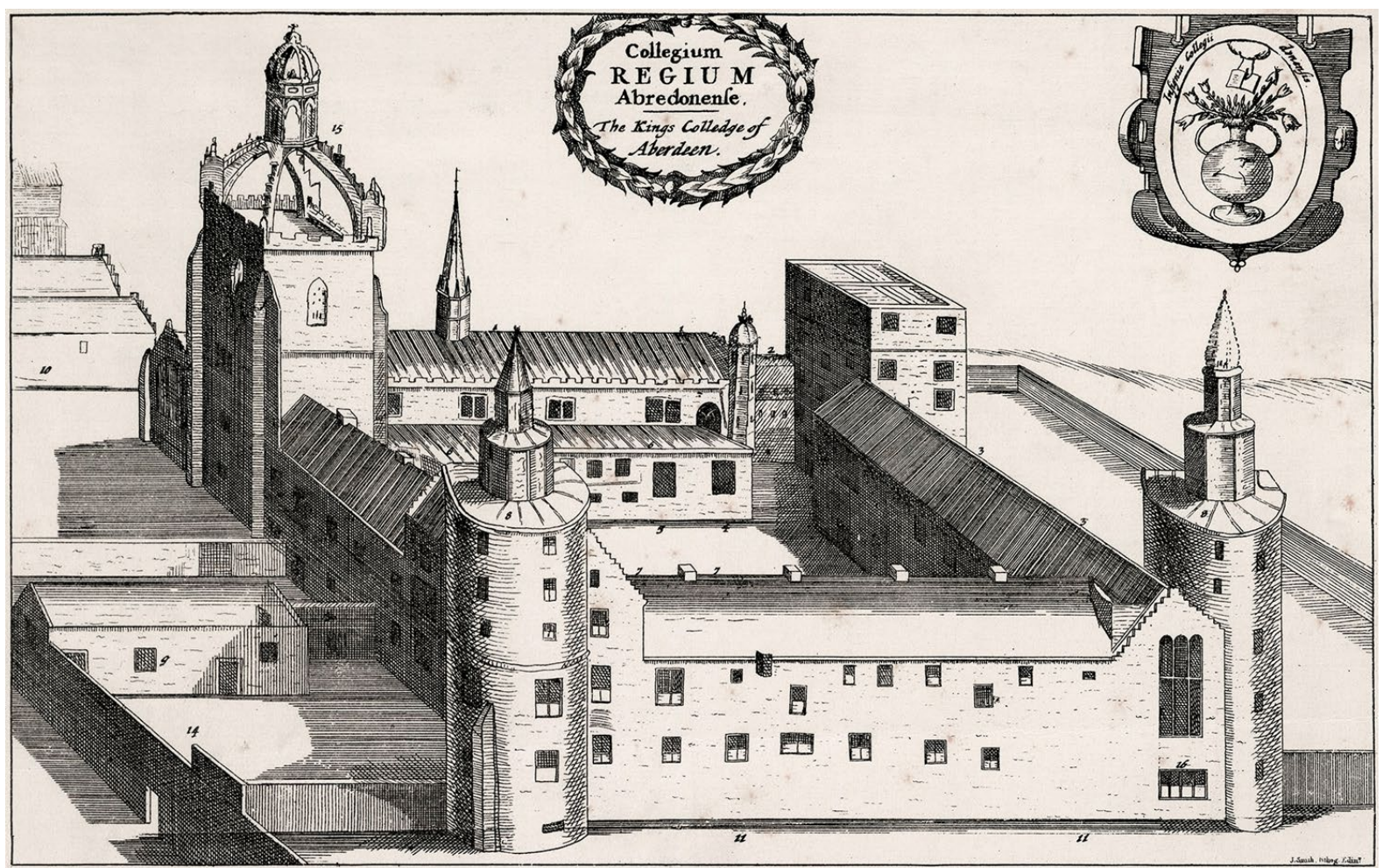

Source: University of Aberdeen Special Collections catalogue number L mAa E Pla.

Reproduced with the permission of the University of Aberdeen

James Gordon's view of King's College from the south-west, drawn around 1660. The drawing shows the Chapel occupying the northern façade, with the iconic Crown Tower top left. The chapel, consecrated in 1509 , remains in use as a place of worship and is also frequently used as a concert performance space. The Cromwell Tower (top right) still houses teaching rooms and staff offices. Bishop Stewart's library and the ground floor sacristy are depicted adjoining the south façade of the chapel; both were demolished in 1772. Occupying the southern side of the complex is Bishop Dunbar's residential block. Today this space is occupied by King's College lecture rooms. James Gordon graduated from King's College in 1636. He was the son of Robert Gordon of Straloch and assisted his father in preparing Pont's 
maps for publication in Blaeu's Atlas novus. James Gordon undertook various cartographic commissions across Scotland in his own right, including a map of the Old and New Towns of Aberdeen in 1661. 
Figure 3. Marischal College Quadrangle, 1861

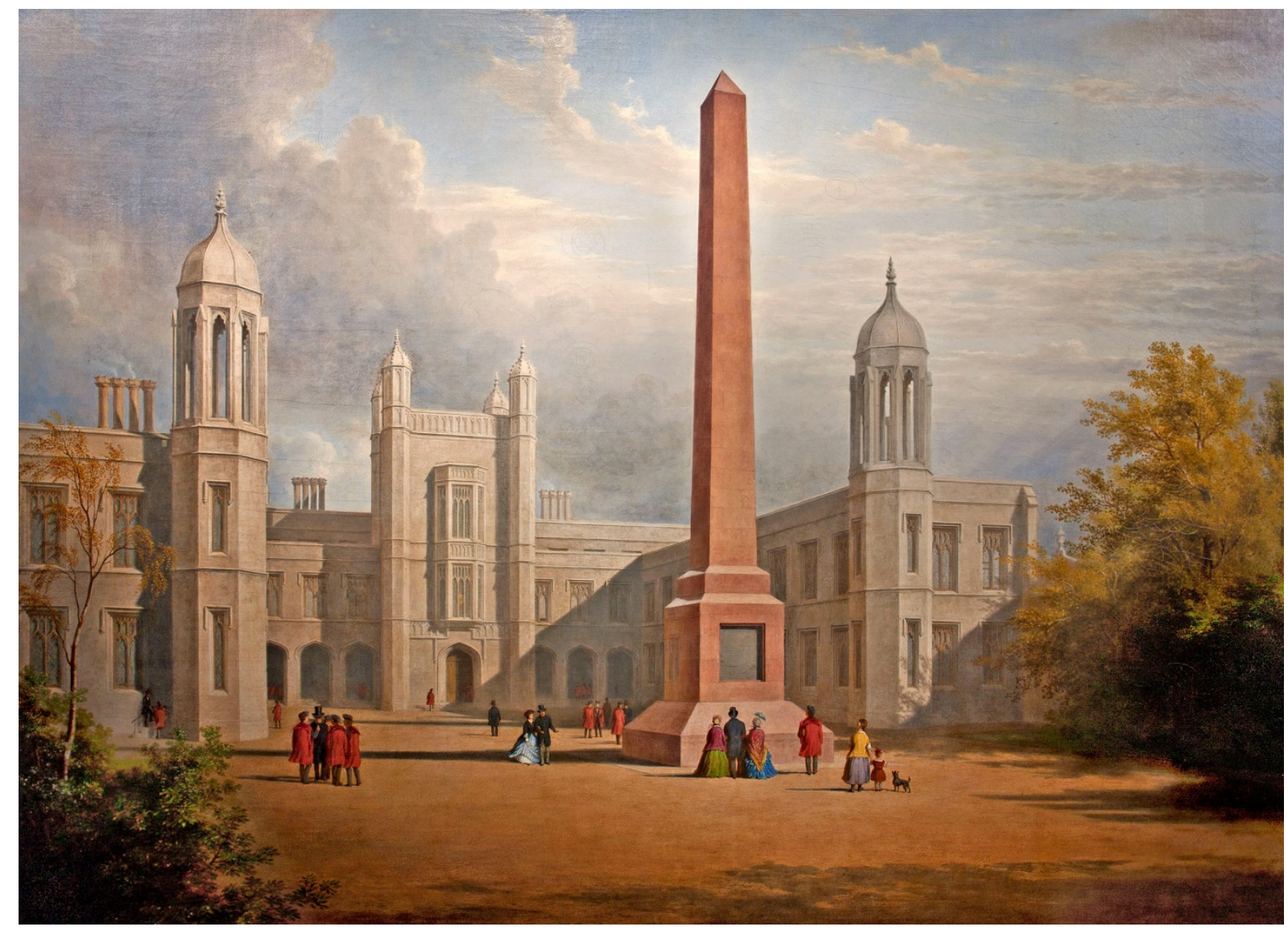

Source: University of Aberdeen Museum and Collections Human Culture Collection, catalogue number ABDUA 30268. Reproduced with the permission of the University of Aberdeen.

Marischal College, from the west, by James Giles, RSA (1861). The obelisk, a monument to Sir James McGrigor, is now in Aberdeen's Duthie Park having been removed during the construction of the western façade in the 1890s. McGrigor was a physician, military surgeon and botanist, and is credited with creation of the Royal Army Medical Corps. He was also Rector of the University of Aberdeen. The image portrays the 'new' Marischal College designed by Archibald Simpson, which opened in 1837 replacing much earlier buildings that by the early 1800 s had fallen into serious disrepair. 
Figure 4. Marischal College, Aberdeen, 1906

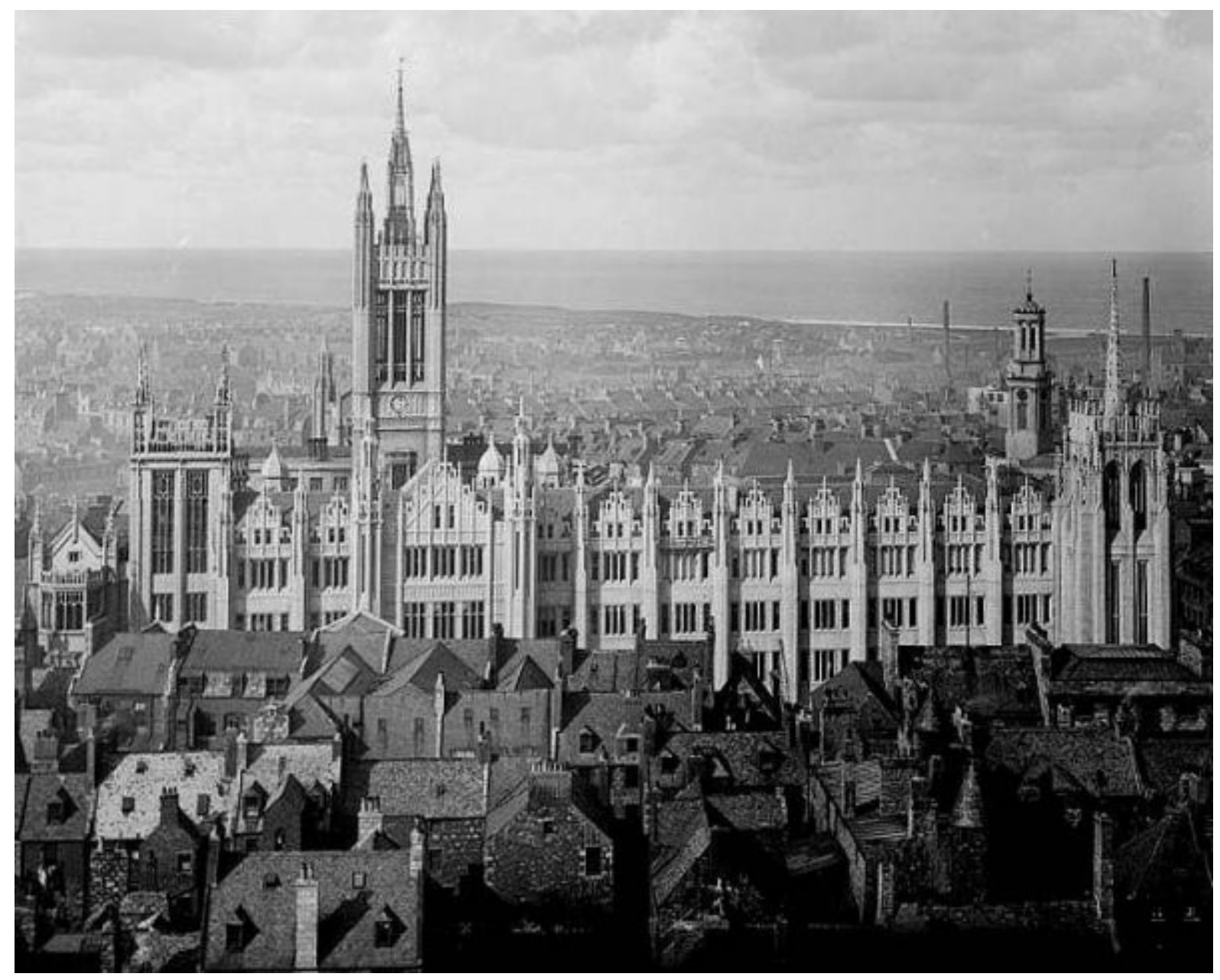

Source: University of Aberdeen, Special Collections, George Washington Wilson Collection, A03416. Reproduced with the permission of the University of Aberdeen.

Marischal College by George Washington Wilson. The image shows the Mitchel Tower and the western façade which were both added to the college buildings as part of the University of Aberdeen's extension scheme of 1892 - 1906. The expanded building, which remains an Aberdeen landmark to this day, was officially opened by King George V in 1906. In the foreground are buildings of Guest Row (one of the earliest streets in the city, demolished as part of slum clearance in the 1930s) and Provost Skene's House, one of the oldest buildings 
in Aberdeen, is visible front right. Much of Marischal College has been leased to Aberdeen City Council for use as their headquarters, but the University of Aberdeen still uses space within the east block which houses the Mitchell Hall, Picture Gallery and the Marischal Museum. 
Figure 5. Front cover of James Downie's 1633-34 dictates

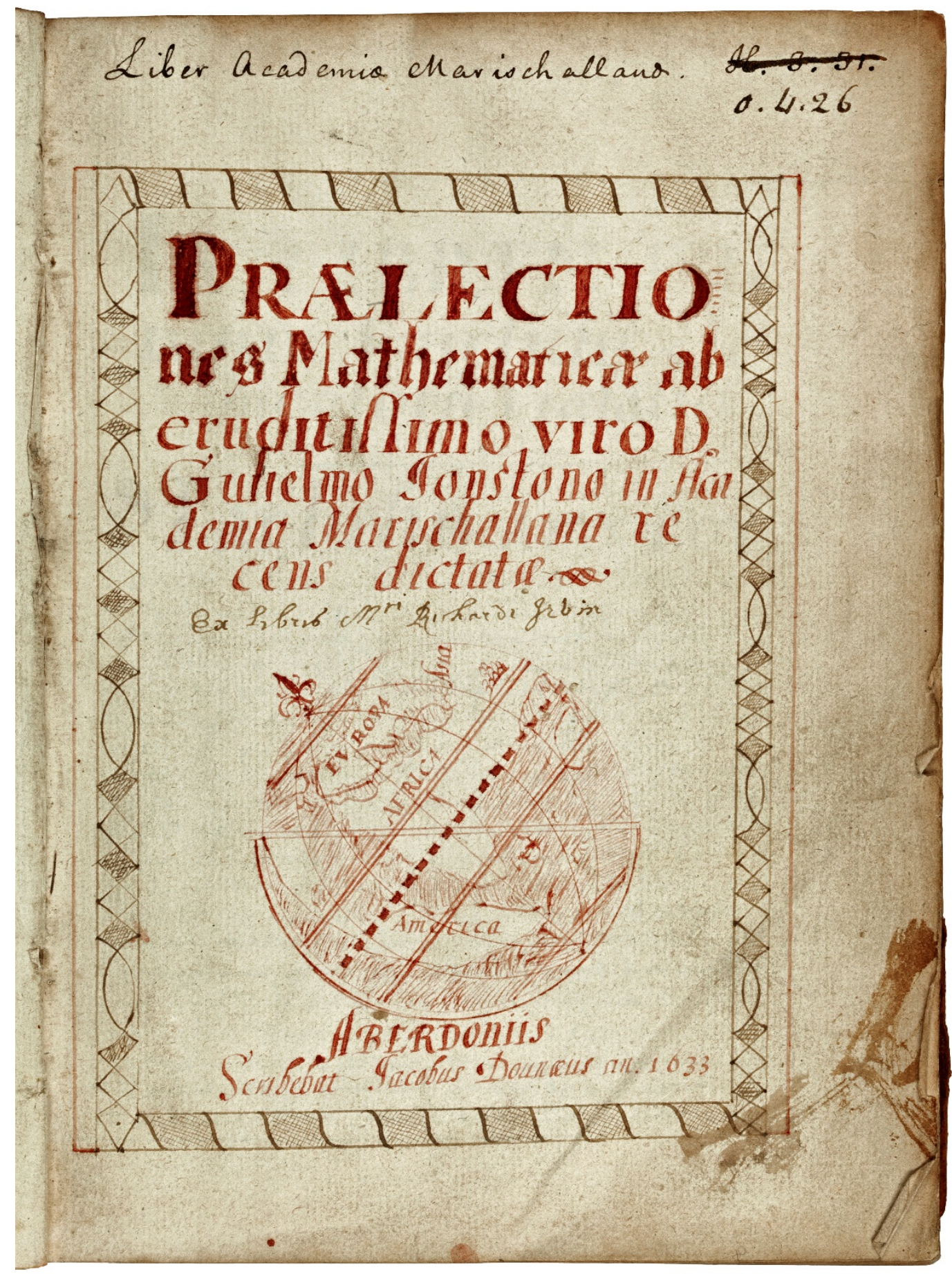

Source: University of Aberdeen, Special Collections, MS 3973. Reproduced with the permission of the University of Aberdeen. 
Early evidence of geographical-chorographical knowledge being imparted to undergraduate students is illustrated by the front cover of the dictates or notes from William Johnston's mathematics lectures taken by James Doun (or Downie) and Richard Irvin in the academic year 1633-1643. 
Figure 6. The Proposed Degree in Commerce

At its meeting on 11 February the University Court, after adjusting the terms of a draft Ordinance submitted by a Committee appointed for the purpose, resolved to communicate the draft to the Senatus and General Council for their opinions. The draft Ordinance provides for the institution of the degree of Bachelor of Commerce; the administration of the regulations for this, subject to the control of the Senatus, by a Board of Studies, till a separate Faculty of Commerce is created in the University, powers for which are also taken; and the appointment of an Advisory Committee of persons experienced in commerce and industry. The preliminary qualification for the curriculum for the degree is stated as the fact of having passed with the Arts or the Science Preliminary examination, or a qualification recognized as excepting from such examinations. The curriculum laid down is one extending over nine terms, or three academical years, and the subjects of instruction are to be studied in courses consisting in all of twenty-one terms attendance. The compulsory subjects, involving fourteen term attendances, are: Political Economy, Organisation of Industry and Commerce, Economic Statistics, Accounting and Business Methods, one Foreign Language, Economic Geography, and Mercantile Law. The additional subjects, involving seven or more term attendances, may be selected from the following: other Foreign Languages or an advanced course in the one already taken, some named subjects in Science or others as the Senatus may approve, Pure Mathematics and Advanced Statistics, Economic History, Constitutional Law and History, Political Science and Sociology, Public and Private International Law (for it is hoped that the degree may be of value to candidates for the Consular service), Public Finance, Advanced Political Economy, Banking, Currency and Foreign Exchanges, Insurance, Industrial Hygiene, Modern History, and such special courses in Industry and Commerce as the Senatus may from time to time sanction. Power is reserved to the Senatus to add or to modify these courses and their groupings with the approval of the Court and after reference to the General Council; and attendance at equivalent courses in other Universities is allowed for. The draft Ordinance is the outcome of a proposal to the University Court by the Aberdeen Chamber of Commerce, consultations with the Chamber's Educational Committee, and prolonged and careful deliberation by committees of the Senatus and Court. To Mr. Glegg, the ex-Chairman of the Chamber, Mr. Davidson, Mr. Jafffrey, and the late Lord Provost Maitland in particular, the University is indebted for the revival of a project formed by the Senatus as far back as 1900 but postponed through want of public support; and for the fact that already the large sum of $£ 18,000$ has been subscribed towards the cost of carrying on the new Department. It is understood that the income from this fund will be applied to the provision of new lectureships in financial and commercial subjects; while the lectureships that will be used in other departments of the University, besides that of Commerce, are to be provided from University funds. The University Court has intimated to the Chamber of Commerce that it is intended to start the courses leading to the degree next October. A number of applications to enter on these have been received from returning officers and soldiers. 
Figure 7. The first Honours Geography syllabus at Aberdeen

\author{
GEOGRAPHY \\ Instituted in 1920 \\ Lecturer - 1920 John McFarlane MA, MCom
}

\title{
I ORDINARY CLASS
}

Three lectures and one hour's practical work a week during each of the three terms.

The subjects of the lectures will be:-

A. General principles - one term.

1. The evolution of topographical features with special reference to the cycle of erosion. The more important factors in the distribution of soils and minerals.

The distribution of land and water. Circulation of oceanic waters.

Climate and weather. The general conditions which determine climate and an analysis of the more important types of climatic regions.

The influence of climate upon soil and vegetation and the conditions controlling the distribution of woodland, grassland and desert. The geographical conditions affecting the distribution of plants of economic value.

The natural regions as determined by the above factors.

2. A general account of the distribution of the more important $b$ ranches of the human race. Racial characteristics.

3. The relation of man to his environment. The nature of geographical control. Relativity of geographical advantage. The influence of geographical conditions upon the development of agriculture, manufactures, and trade. The distribution of population, the position and growth of towns, and the development of communications. Influence of environment upon the development of various types of political and social organisation. The nature of Historical Geography.

\section{B. Regional Geography - two terms}

In the second and third terms, the principles discussed in the first term will be applied in a regional study of the earth's surface. The work of the practical class will incloud7e a non-mathematical knowledge of the more useful map projections, map construction, map reading and the use of simple geographical instruments. During the summer term excursions will, if possible, be substituted for this class.

\section{ADVANCED CLASS}

Three lectures and one hour's practical work during each of the three terms.

In this class a more intensive study will be made of a prescribed region and students will be expected to read some of the more authoritative works on it.

The practical class will consist of the study of maps, illustrating physical and climatic phenomenon and the conditions of human activity in various parts of the selected regions, and other work of similar character.

(The advanced class will first meet during the session 1921-22, when Europe will be the prescribed region).

\section{HONOURS CLASS}

Three lectures a week during each of the three terms. Candidates for Honours who can so arrange it are advised to attend the class during two consecutive years.

The subjects of the course will include:-

1. The outlines of Human Geography

2. The detailed study of prescribed regions

3. The consideration of special problems in Geography - physical, climatic and economic

(This class will meet for the first time during session 1922-23

Source: The Aberdeen University Calendar for the year 1920-21 (pp. 95-96). 
Figure 8. Early Geography field excursions
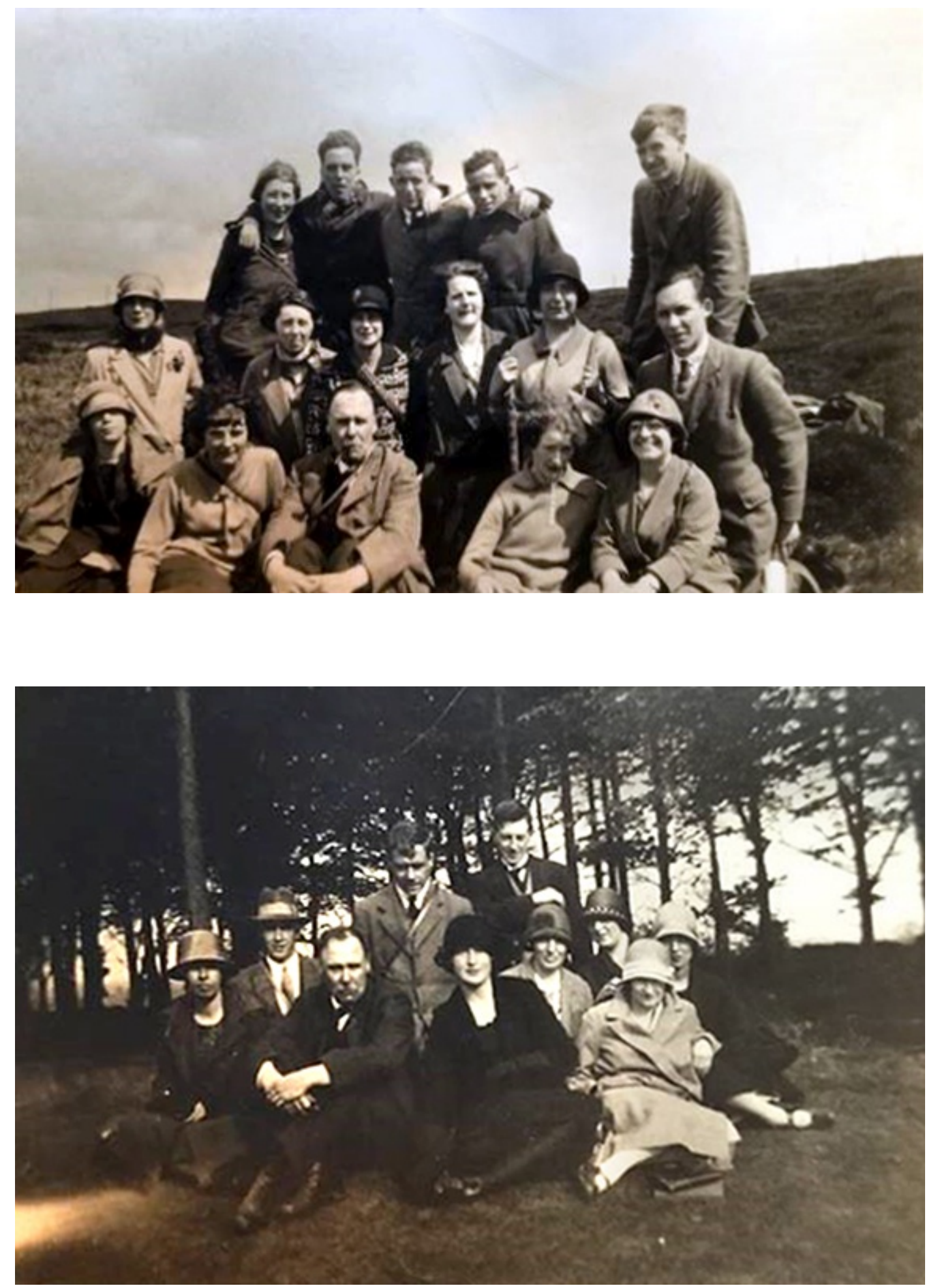

Photographs reproduced with the permission of the McFarlane family. 
Figure 9. Student numbers in Geography, 1919-20 to 1944-45

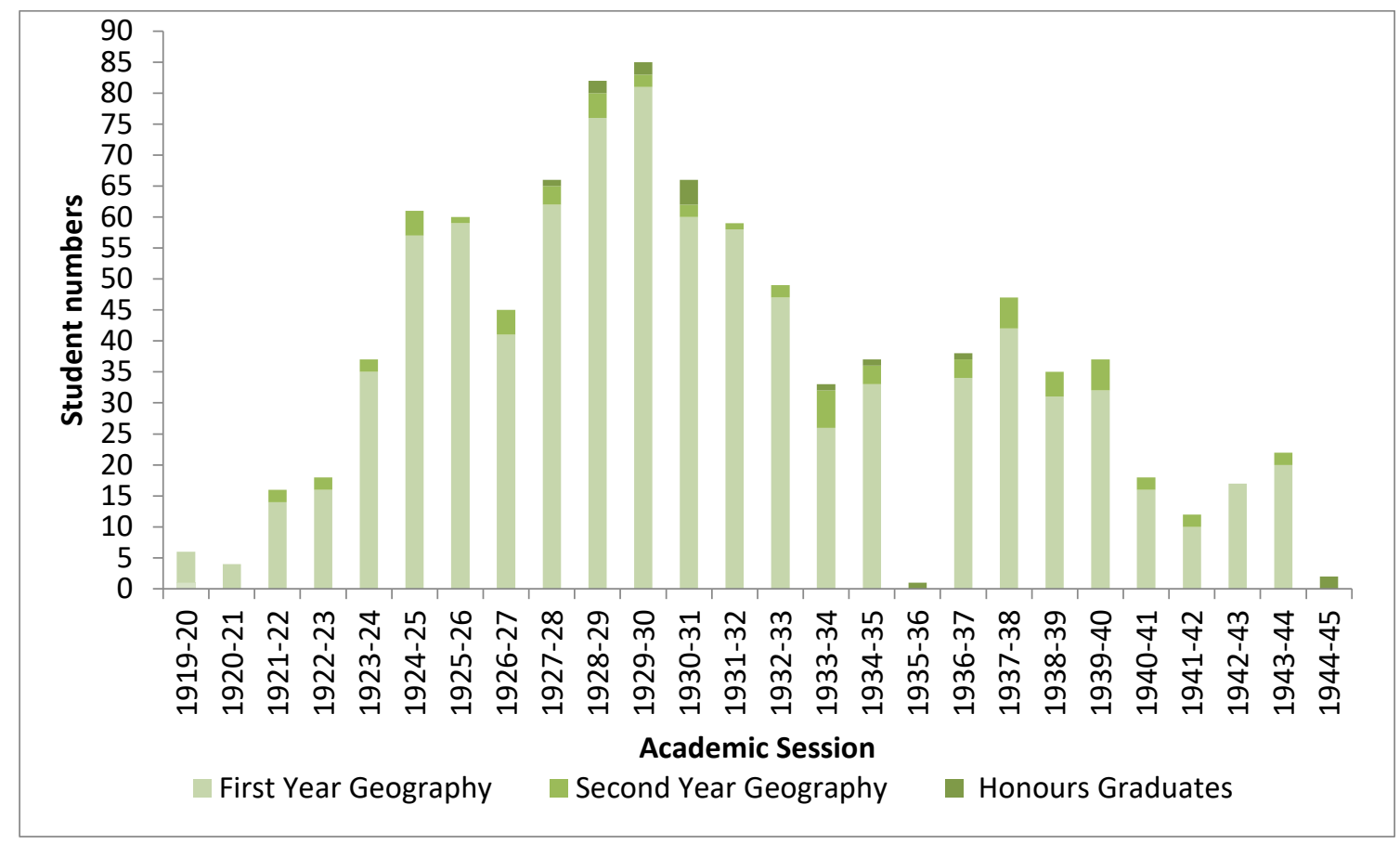


Figure 10. Number and gender of Honours Graduates in Geography, 1948-1964

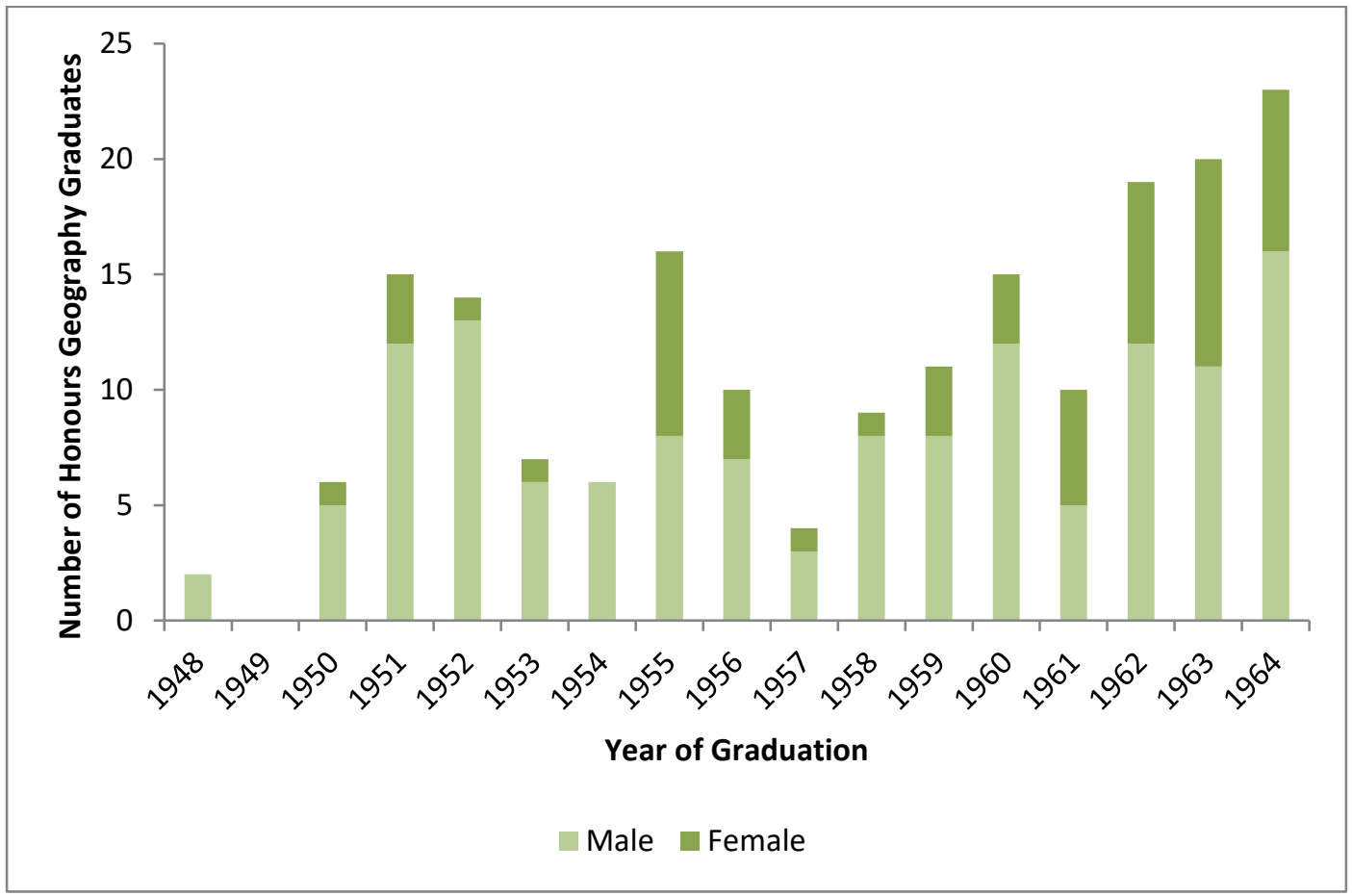

Source of data: 'Honours Graduates in Geography, 1948-1964' compiled by James Coull, The Orb (1964) pp. 40-43. 
Figure 11. Front cover and Editorial The Orb Vol. 1 No. 1, May 1949
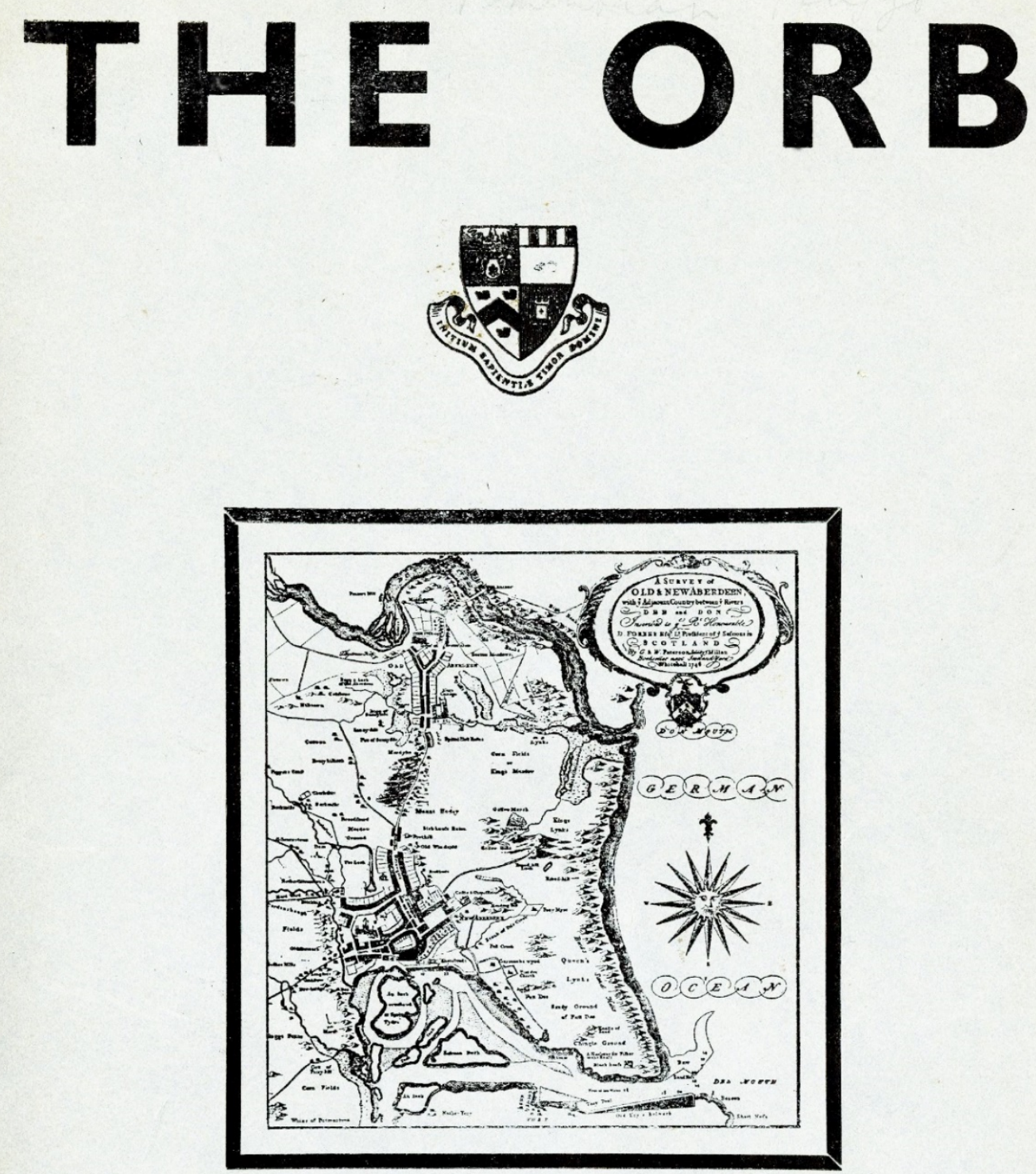

MAGAZINE OF THE

\section{ABERDEEN UNIVERSITY GEOGRAPHICAL SOCIETY}


The Joumal of the Aberdeen University Geographical Society.

Vo1.1 No. 1 MAY, 1949

\section{PDITORIAI}

A new venture - a Society Nagazine. Born in this post-war intellectuel boom, this number, we hope, is the first of an everexpanding ublication. May it nover be "the first of the few". It is a tribute to the active co-operation of the members of the Society. Mith very limited financial resources the task has been difficult, and consequently at the moment we are unable to produce a printed magazine or to publish all the informative and amusing articles we have received. However, we are confident that this little disadvantage will be remedied in the future. I would like to take this opportunity of thanking R.H.Cairns, and B. N. Nood for their invaluable eiforts on the Bditorial Commitiee; and without the assistance of J.H.Johnstone and R. Gray in the preparation of proofs it seems unlikely that our task would have reached completion.

A toasti to the fuivre of rhe Orb. May, 1949.

$$
\text { J.I.CIARKE. }
$$

\section{$-0000000-$}

THE YEAR IN THE DEPARTMENT

The session $\overline{19} 48-194 \overline{9}$ has seen a furter substantial rise in the numbers of students, and the fact that this rise has been proportionately higher than the eneral increase in admissions to the University is an encouraging sign for the future. Te can, however, in some respects still regard the Department as forming part of the "Pioneer Fringe" of Geography in Scotland. Because of the reduction in length of course for ex-forces students whose studies were interrupted, there cre no fourth year students at present; but Junior Honours sumper 6, Advanced 21, and Ordinary 85. During the Baster Vacation some 52 students and staff at ended a field excursion to Bdinburgh, York, and Dent: whilst in the previous Ionf Vacation, smaler parties visited industrial Lancashire and the rest Riding, and Switzeriand.

Lack of spece and equipment heve been considerable handicaps, but early entry is promised to the new buildin, and the present crar ed situation should improve considerably - even to the extent of having seeting that will allow all sudents io face the blackboard The staff has been increased by the appointment of Nir.K. Walton M.A. (Ddin.) as research fellow; and two fur her appointments are to be made shortly. In this way it is intended to extend the teaching in the Departnent so as to allow increased specialisation as between Arts and Science. One feature of interest during the session hes been the inclusion of a course on the Geography of France as part of the Honours syllabus in French. A number of

Note: The first editor of The Orb was John Clarke, who graduated in 1950. Following doctoral research at the University of Paris Clarke held an Assistant Lecturer position in Geography at Aberdeen during the session 1954-55 before moving to the University of Durham where he became the third academic to hold a Chair in Geography in 1968. 
Figure 12. The members of the First Viking Congress, Lerwick, Shetland, July 1950. The Aberdeen personnel are indicated (after Simpson 1954, frontispiece).

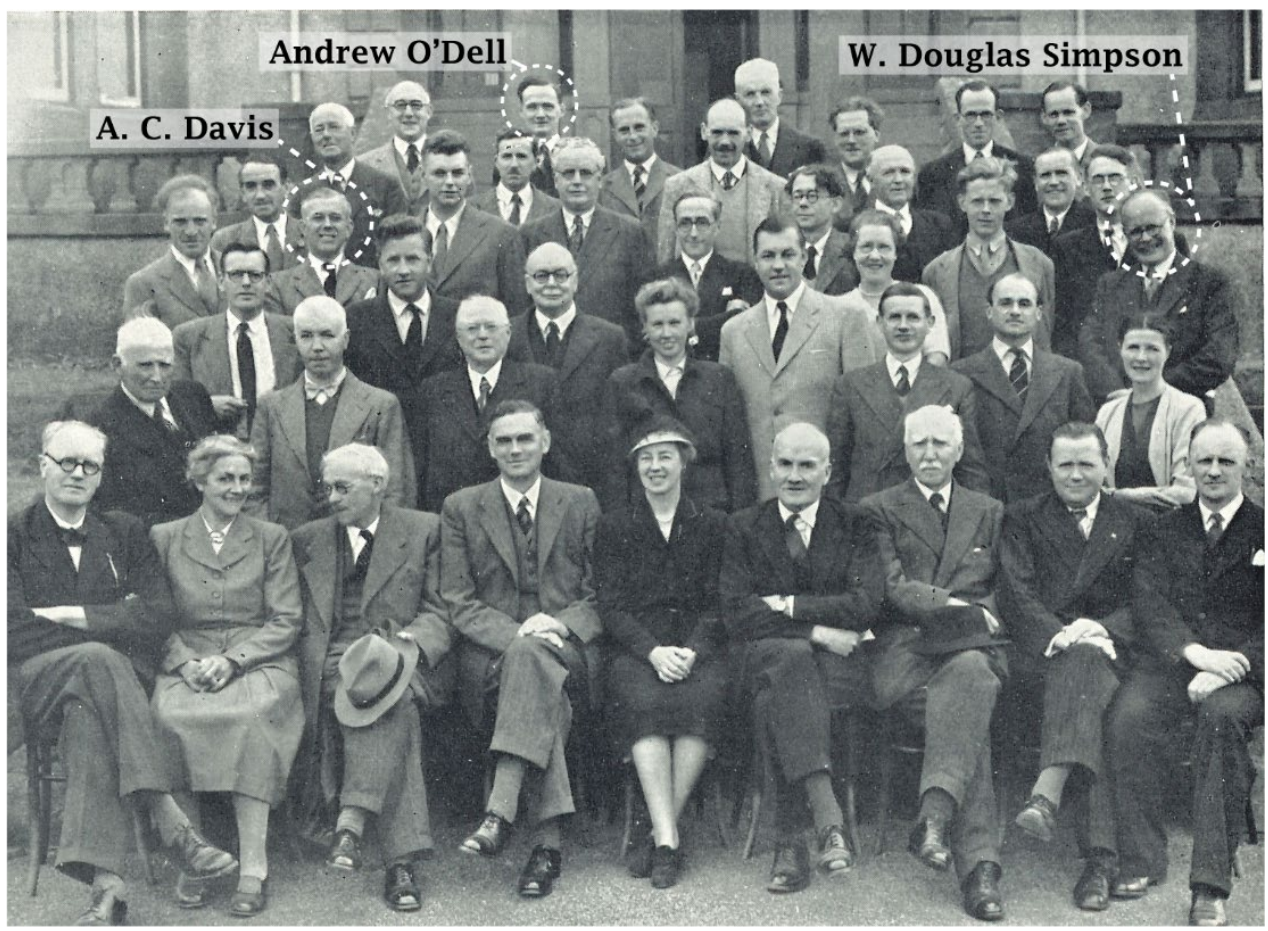

Source: Simpson, W.D. 1954. The Viking Congress: Lerwick, July 1950. Edinburgh: Oliver \& Boyd (for the University of Aberdeen). 
Figure 13. Geography undergraduate student numbers $1955-56$ to $1969-70$

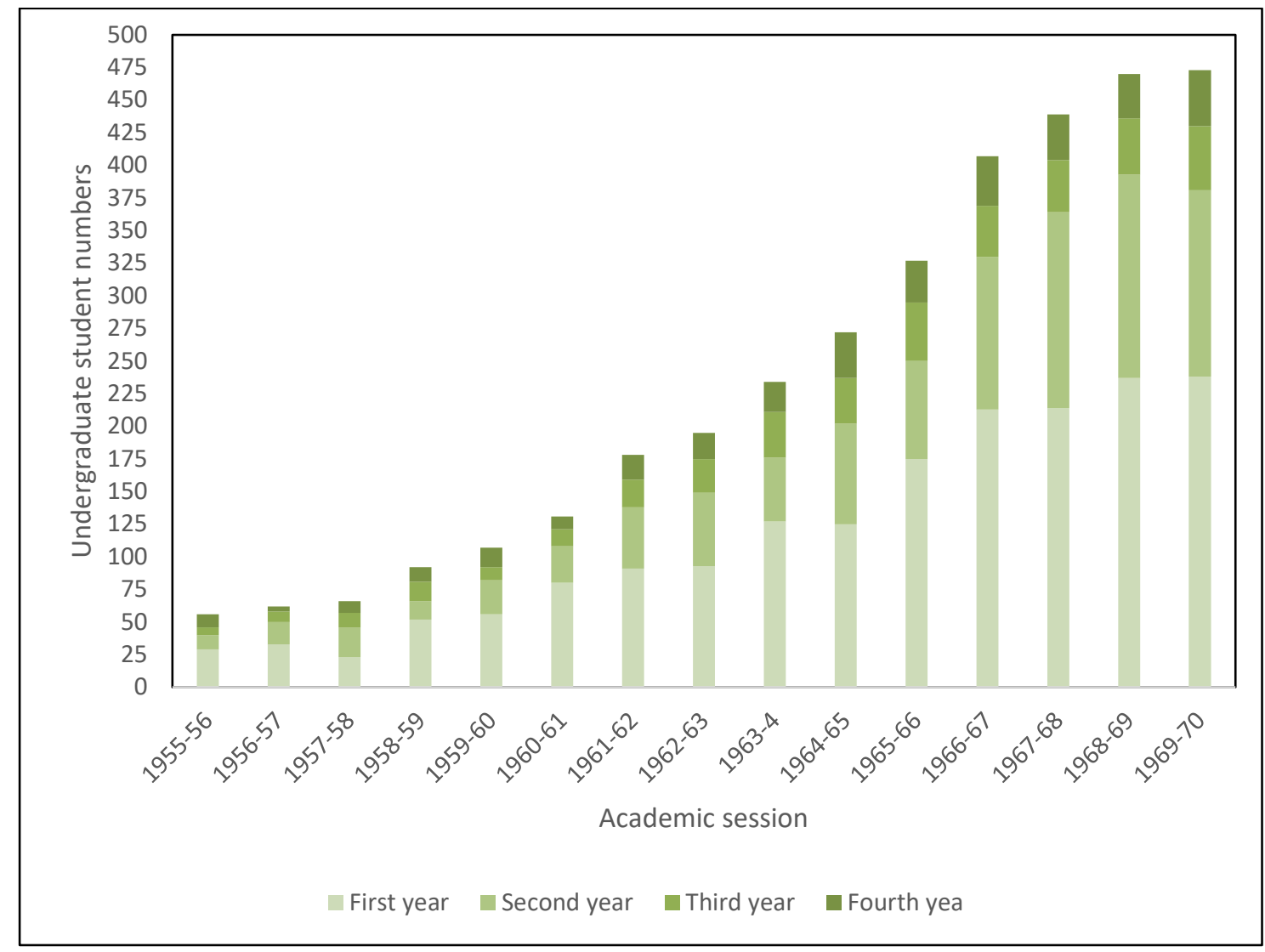


Figure 14. Geography academic staff numbers, 1945-46 to 2018-19

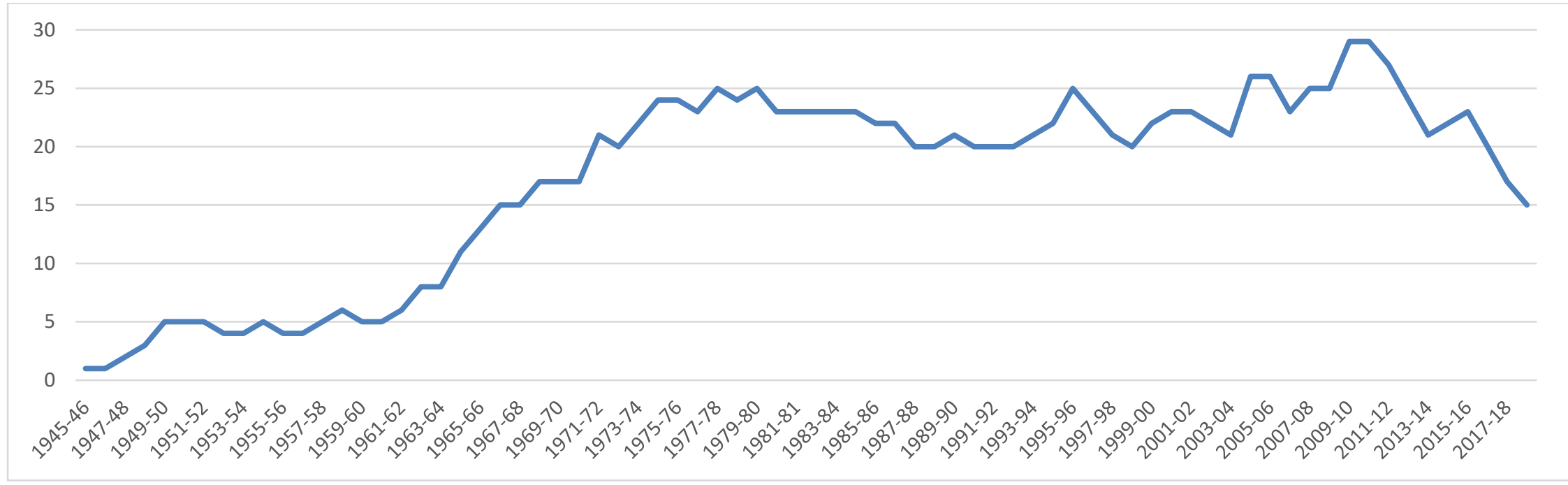


Figure 15. St Mary's, original front elevation

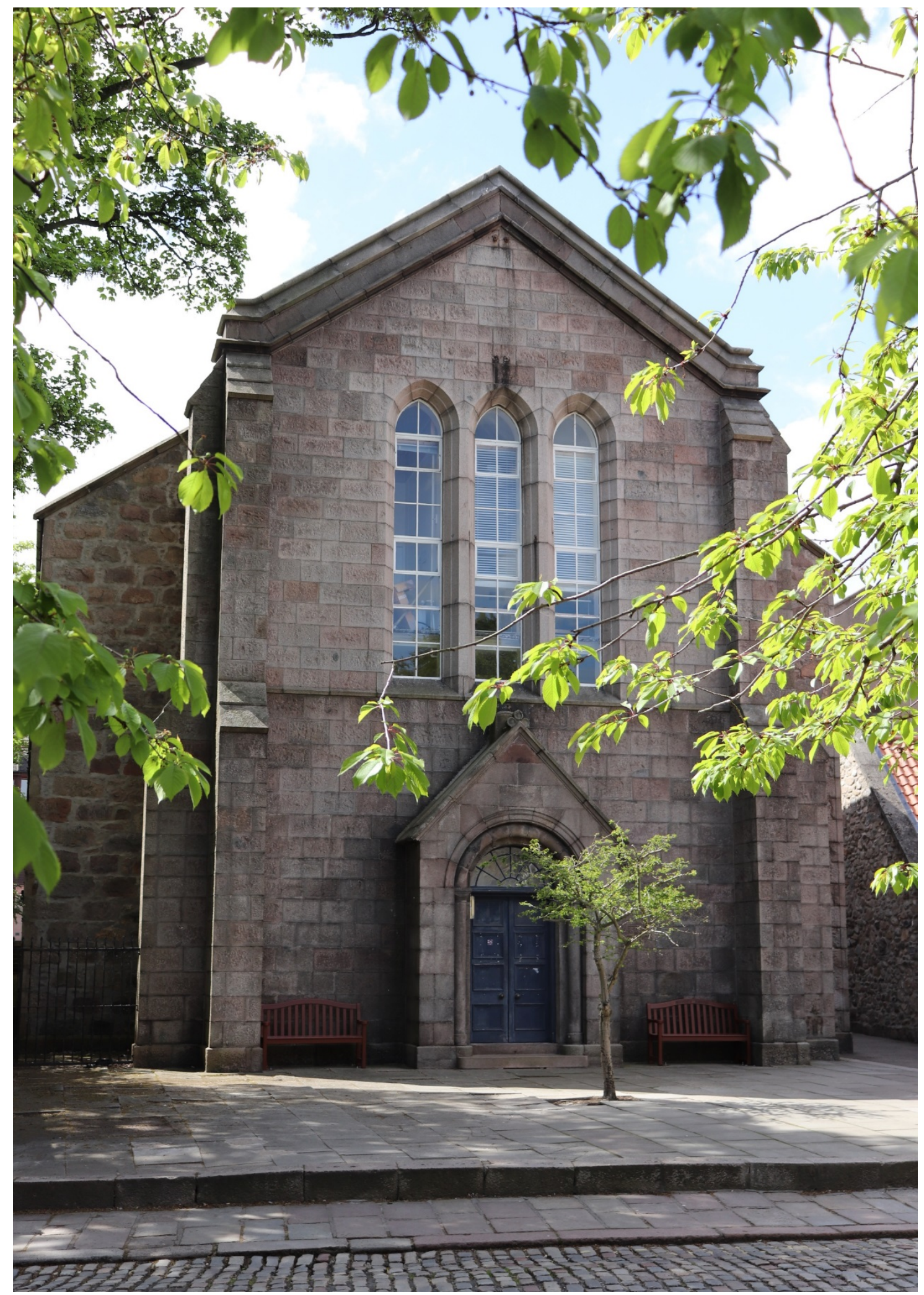

Source: Departmental photographic archive (photographer Jamie Bowie) 
Figure 16. The first extension to St Mary's and a new front entrance

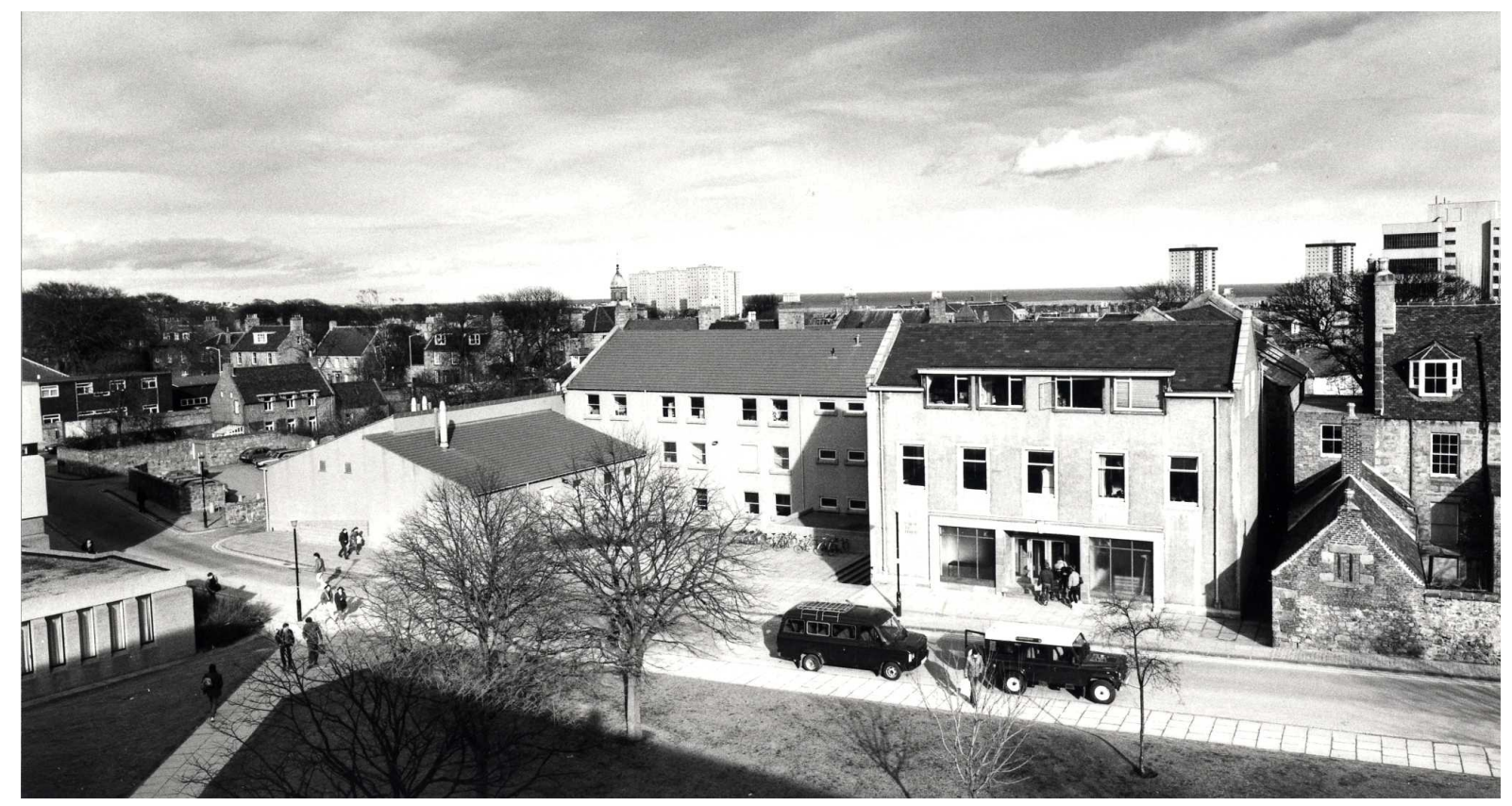

Source: Departmental photographic archive.

The (first) extension to St Mary's opened in 1968. This undated image was taken some time in the late 1980s or early 1990s, following the development of the second extension and before the construction of the Elphinstone Road student flats. Note the Departmental Land Rover and a second Departmental vehicle in the foreground. 
Figure 17. Tarradale House

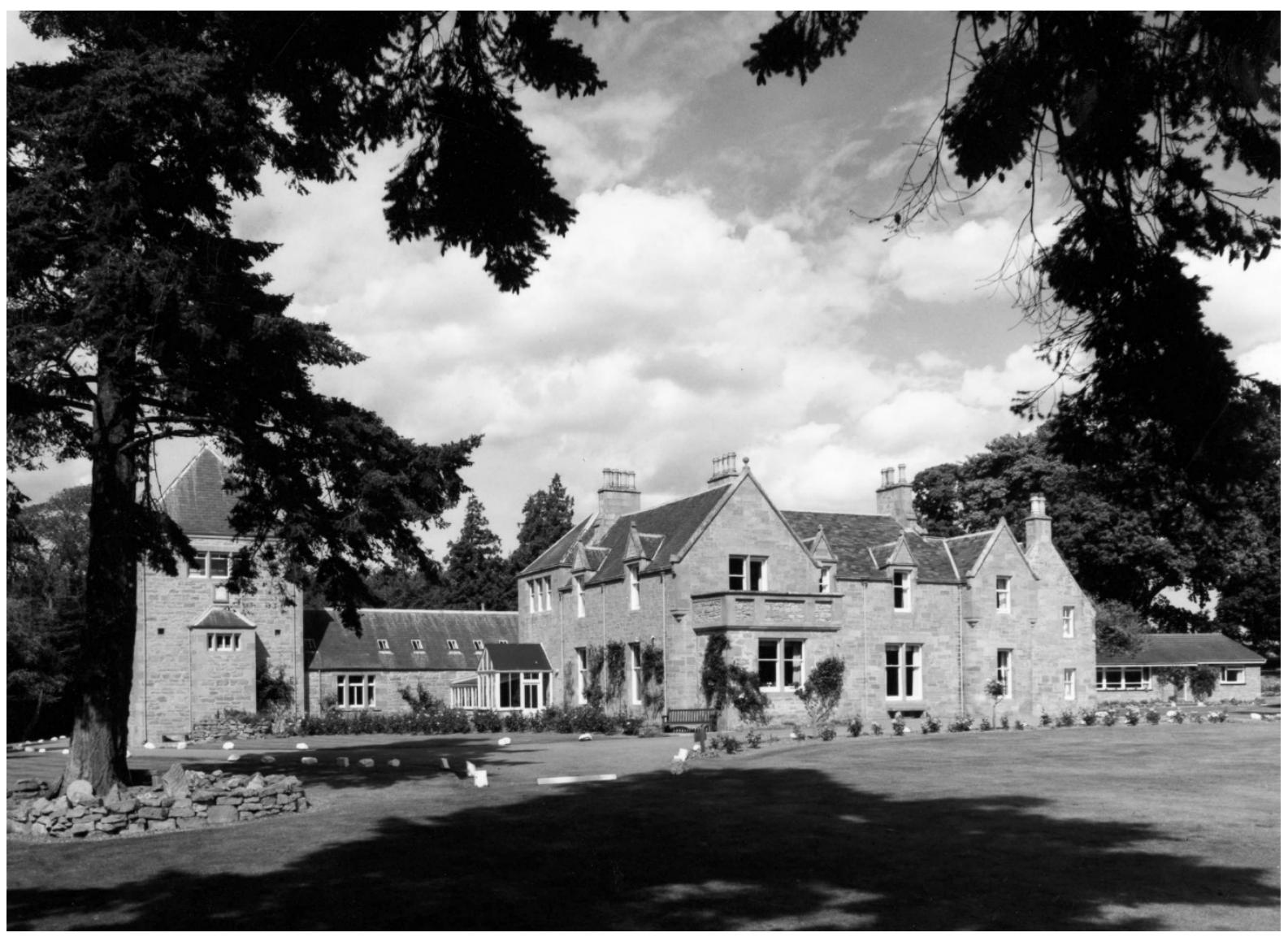

Source: Departmental photographic archive. 
Figure 18. Numbers of Honours Graduates in Geography 1970-71 to 1989-90

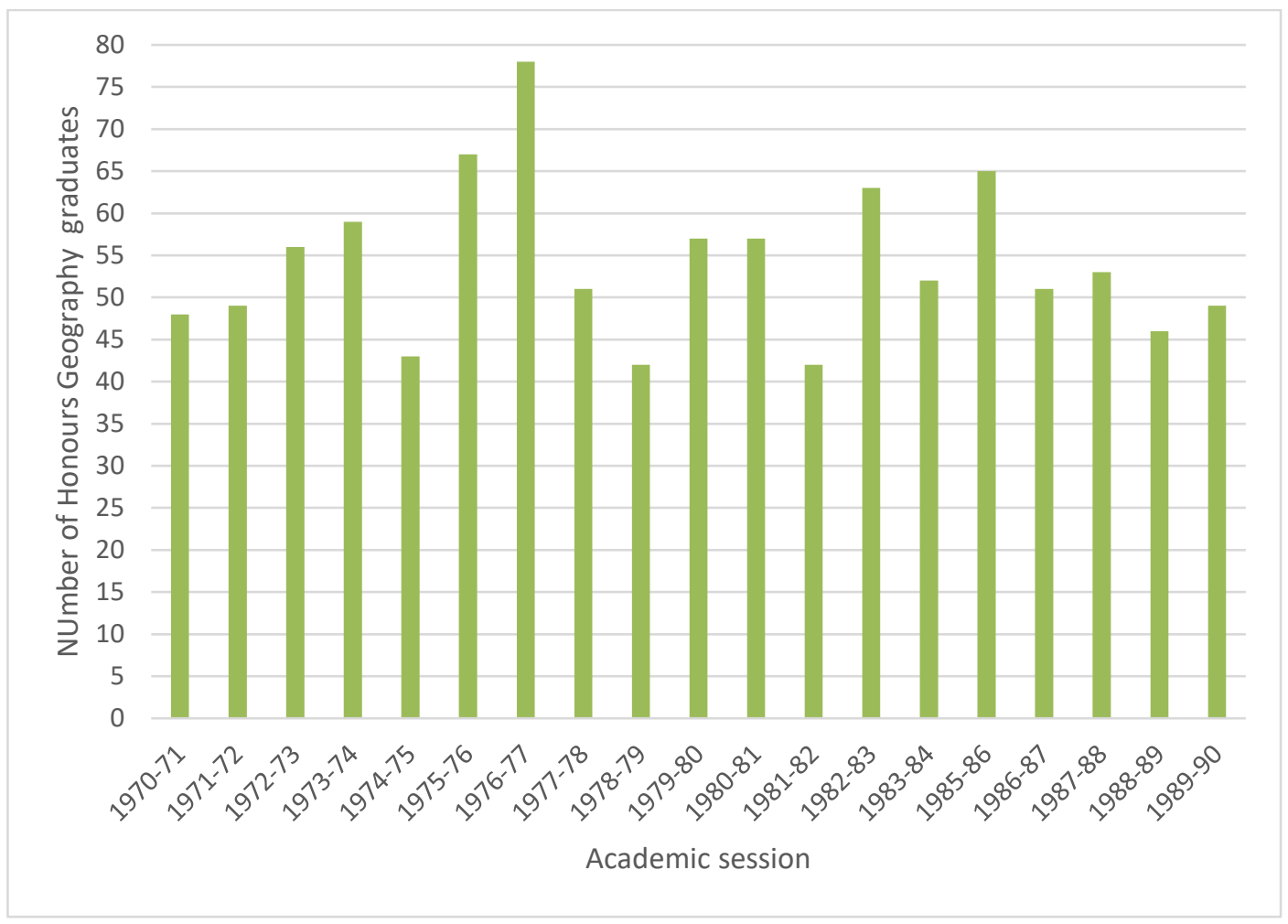


Figure 19. Development of the second extension to St Mary's, winter 1979 - 1980
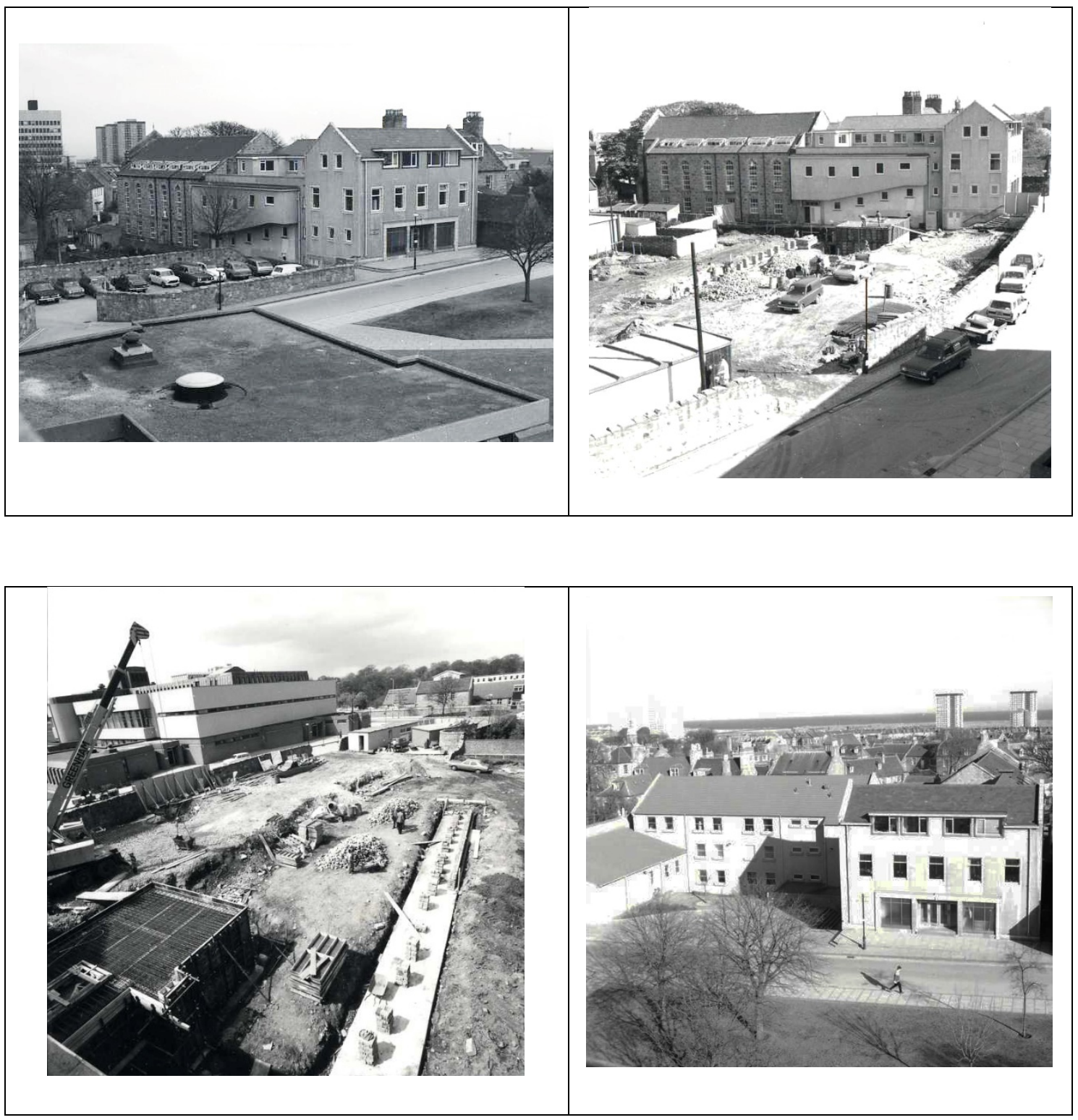

Source: Departmental photographic archive.

Clockwise from top left: staff car park to be replaced by a second extension to St

Mary's; site clearance commences; the ground floor of the extension takes shape;

extension completed. 
Appendix 1: Recommended reading for Ordinary and Advanced Geography, 1921-22

Recommended reading for the Ordinary Geography class, 1921-22

The following books may be consulted in connection with the lectures: Lake's Physical Geography; De Martonne's Traité de Géographie Physique; Ward's Climate; Dickson's Climate and Weather; Hardy's The Geography of Plants; Haddon's The Wandering of Peoples; Keane's Man, Past and Present; the Introduction to Chisholm's Commercial Geography; Mill's International Geography; McFarlane's Economic Geography; Hinks' Maps and Survey.

Recommended reading for the Advanced Geography class, 1921-22

The following works may be consulted: MacKinder's Britain and the British Seas; Partsch's Central Europe; Lyde's The Continent of Europe; Hogarth's The Nearer East; McFarlane's Economic Geography; Ripley's Races of Europe; Newbiggin's Geographical Aspects of Balkan Problems and Aftermath; Keane's Man, Past and Present

Source: The Aberdeen University Calendar for 1921-22, p. 99. 
Appendix 2: Advanced Geography examination paper from session 1924 - 1925 when the regional focus of the Advanced Class was North America.

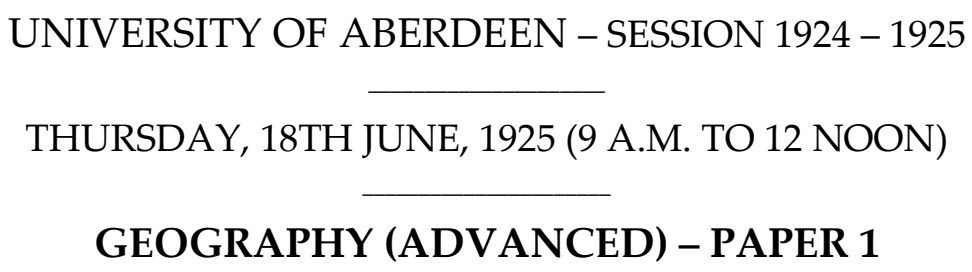

Not more than FIVE questions to be attempted

1.- Write an explanatory account, accompanied by sketch maps or diagrams, of the physical geography of the Middle Appalachian States.

2.- Explain carefully the regional and seasonal distribution of rainfall in North America west of the Rocky Mountains.

3.- Discuss the influence of geographical conditions upon the development of the American colonies during the seventeenth and eighteenth centuries.

4.- "The chief cities of the Interior Lowlands are strategic transport centres. That is to say, today, they are great railway junctions". TO what extent does this statement explain the importance of Chicago, St Louis, and Duluth?

5.- Discus the influence of soil and climate upon the production of cotton in the United States.

6.-“What is provided beyond a doubt is that enormous entirely new areas in the north-west (of Canada) are suitable climatologically for wheat growing, quite apart from the very big areas still uncultivated within the present belt". Discuss this statement.

7.- Write a brief geographical sketch of Alaska.

8.- What do you know of any two of the following:

(a) The historical and economic importance of the Mohawk Valley;

(b) The Ozark Highland;

(c) The Southern Long-Lead Pine Belt;

(d) The Highlanders of the Southern Appalachian?

9.- Discuss the influence of geographical conditions upon the distribution of the population of Mexico.

Source: University of Aberdeen Exam. Papers 1925. University of Aberdeen Special Collections, L Aa P72 Exa. 
Appendix 3: Graduation in Arts Order of Study and regulations for BSc Honours, 1921-22

Graduation in Arts. Order of Study

Geography: The Ordinary graduation class and in a subject from the Department of Language and Literature should be taken during the first year, Advanced Geography, Geology and History or Political Economy (as a Pass subject) during the second. In the third year students should attend the Advanced and Honours classes in Geography and the Ordinary class in the supplementary Honours subject (History or Political Economy) and in the fourth the Honours Class in Geography and the Supplementary Honours subject.

(Source: The University of Aberdeen Calendar for the year 1921-22, p. 185)

BSc Degree with Honours

A candidate who has passed the First or Intermediate Examination and has completed a course of study for the Second or Final Examination may offer himself for examination for the Degree of BSC with Honours under the following conditions:-

(1.) The candidate must, after having passed the whole of the Second or Final Examination for the Ordinary Degree of Bachelor of Science, devote at least one academical year of three terms exclusively to advanced study in the University in one of the subjects professed by him for the Second or Final Examination.

(2.) The candidate must have obtained a certificate of attendance on the approved course or courses of advanced study in a subject professed by him for the degree of BSc. with Honours.

(3.) Candidates must satisfy the Examiners as to their proficiency in practical work forming part of the approved course or courses in a subject.

(Source: The University of Aberdeen Calendar for the year 1921-22, p. 383)

Note 1. In Geography practical work consisted of the preparation of a thesis on an approved region.

Note 2. BSc students took the same Geography classes as students on the MA but were also required to take 'at least two hours practical work a week' alongside the Ordinary and Advanced class lectures.

Source: The Aberdeen University Calendar for 1921-22, p. 383. 
Appendix 4: Academic staff in the Department of Geography 1919 - 2019, by academic year appointed

\begin{tabular}{|c|c|c|}
\hline Name & Academic Year appointed & Academic Year left \\
\hline John McFarlane & $1919-1920$ & $1944-1945$ \\
\hline Alexander Bremner & $1929-1930$ & $1940-1941$ \\
\hline Andrew O'Dell & $1945-1946$ & $1966-1967$ \\
\hline Winifred Day & $1947-1948$ & $1951-1952$ \\
\hline William B. Fisher & $1948-1949$ & $1953-1954$ \\
\hline Kenneth Walton & $1949-1950$ & $1979-1980$ \\
\hline William Kirk & $1949-1950$ & $1958-1959$ \\
\hline John Clarke & $1954-1955$ & $1954-1955$ \\
\hline Archibald McPherson & $1954-1955$ & $1956-1957$ \\
\hline Archibald Fraser & $1957-1958$ & $1960-1961$ \\
\hline Roy Mellor & $1957-1958$ & $1986-1987$ \\
\hline Pat Baird & $1958-1959$ & $1958-1959$ \\
\hline Jimmy Coull & $1959-1960$ & $1996-1997$ \\
\hline Patrick Hamilton & $1961-1962$ & $1996-1997$ \\
\hline Alan Small & $1961-1962$ & $1968-1969$ \\
\hline E. Alistair Smith & $1962-1963$ & $1989-1990$ \\
\hline Chalmers Clapperton & $1962-1963$ & $1998-1999$ \\
\hline William Ritchie & $1964-1965$ & $1994-1995$ \\
\hline David Turnock & $1964-1965$ & $1968-1969$ \\
\hline Martin Wild & $1964-1965$ & $1967-1968$ \\
\hline John S. Smith & $1965-1966$ & $2000-2001$ \\
\hline Jeffrey Stone & $1965-1966$ & $1991-1992$ \\
\hline Francis Synge & $1966-1967$ & $1968-1969$ \\
\hline David Sugden & $1966-1967$ & $1986-1987$ \\
\hline Sandy Mather & $1967-1968$ & $2006-2007$ \\
\hline Eric Naylor & $1967-1968$ & $1995-1996$ \\
\hline Ronald Jones & $1968-1969$ & $1971-1972$ \\
\hline Bobby Wright & $1968-1969$ & $2007-2008$ \\
\hline John Farrington & $1969-1970$ & $2015-2016$ \\
\hline Allan Hill & $1969-1970$ & $1977-1978$ \\
\hline Mike Wood & $1969-1970$ & $2006-2007$ \\
\hline Keith Chapman & $1971-1972$ & $2005-2006$ \\
\hline Brian Clark & $1971-1972$ & $1999-2000$ \\
\hline Rod Gunson & $1971-1972$ & $2000-2001$ \\
\hline Lawrie McLean & $1971-1972$ & $2010-2011$ \\
\hline Brian Beeley & $1973-1974$ & $1975-1976$ \\
\hline John Loder & $1973-1974$ & $2011-2012$ \\
\hline Alastair Gemmell & $1973-1974$ & $2011-2012$ \\
\hline Peter Stanley & $1974-1975$ & $1979-1980$ \\
\hline Nicholas Stephens & $1974-1975$ & $1977-1978$ \\
\hline
\end{tabular}




\begin{tabular}{|c|c|c|}
\hline Ian Ralston & $1977-1978$ & $1984-1985$ \\
\hline Nick Williams & $1977-1978$ & $2002-2003$ \\
\hline Judith Maizels & $1979-1980$ & $1995-1996$ \\
\hline David Green & $1988-1989$ & in post \\
\hline Kenneth Lynch & $1992-1993$ & $1992-1993$ \\
\hline Doug Benn & $1993-1994$ & $1997-1998$ \\
\hline Chris Soulsby & $1993-1994$ & $2015-2016$ \\
\hline Andy Cumbers & $1994-1995$ & $1999-2000$ \\
\hline John Bryden & $1995-1996$ & $2004-2005$ \\
\hline Alexandra Hughes & $1995-1996$ & $1997-1998$ \\
\hline Colin Hunter & $1995-1996$ & $2011-2012$ \\
\hline Nick Spedding & $1995-1996$ & in post \\
\hline Hayden Lorimer & $1998-1999$ & $2005-2006)$ \\
\hline Rob Malcolm & $1999-2000$ & $2001-2002$ \\
\hline Jon Shaw & $1999-2000$ & $2005-2006$ \\
\hline Kevin Edwards & $2000-2001$ & $2017-2018$ \\
\hline Chris Gibbins & $2000-2001$ & $2017-2018$ \\
\hline William Walton & $2001-2002$ & $2012-2013$ \\
\hline Danny MacKinnon & $2001-2002$ & $2009-2010$ \\
\hline Andy McMullen & $2001-2002$ & $2003-2004$ \\
\hline Ian Lawson & $2004-2005$ & $2004-2005$ \\
\hline Lorna Philip & $2004-2005$ & in post \\
\hline Brice Rea & $2004-2005$ & in post \\
\hline Adam Barker & $2004-2005$ & $2004-2005$ \\
\hline Steve Tiesdell & $2004-2005$ & $2004-2005$ \\
\hline Aileen Stockdale & $2004-2005$ & $2005-2006$ \\
\hline Douglas MacMillan & $2004-2005$ & $2005-2006$ \\
\hline Alastair Dawson & $2005-2006$ & $2013-2014$ \\
\hline Dmitri Mauquoy & $2005-2006$ & in post \\
\hline Tim Mighall & $2005-2006$ & in post \\
\hline Sergei Shubin & $2005-2006$ & $2010-2011$ \\
\hline Helmut Geist & $2006-2007$ & $2012-2013$ \\
\hline Doug Mair & $2006-2007$ & $2015-2016$ \\
\hline Antonio Ioris & $2007-2008$ & $2012-2013$ \\
\hline John Nelson & $2007-2008$ & $2016-2017$ \\
\hline Ed Schofield & $2007-2008$ & in post \\
\hline Doerthe Tetzlaff & $2007-2008$ & $2015-2016$ \\
\hline Jillian Anable & $2008-2009$ & $2016-2017$ \\
\hline Mark Beecroft & $2009-2010$ & in post \\
\hline Rob Bingham & $2009-2010$ & $2013-2014$ \\
\hline Matteo Spagnolo & $2009-2010$ & in post \\
\hline David Watts & $2009-2010$ & $2017-2018$ \\
\hline Caitlin Cottrill & $2013-2014$ & in post \\
\hline Jean-Christophe Comte & $2014-2015$ & in post \\
\hline
\end{tabular}




\begin{tabular}{|l|l|l|} 
Josie Geris & $2014-2015$ & in post \\
\hline Piotr Niewiadomski & $2014-2015$ & in post \\
\hline Tavis Potts & $2015-2016$ & in post \\
\hline Katrin Prager & $2018-2019$ & in post \\
\hline
\end{tabular}

Notes

1. The list names the 'core funded academic staff'. It does not include Teaching Fellows, research staff or fractional Chair appointments, although their contribution to the life of the Department has been considerable.

2. Where possible, dates noted in the table are as listed in the University Calendar. Staff lists ceased to be published in 1997-1998. Arrivals and departures since then are based on the personal recollections of the authors and other current and recently retired members of staff. 
Appendix 5: O'Dell Memorial Monographs Series

1. W. Ritchie (1968) The coastal geomorphology of North Uist

2. J.R. Coull (1971) Crofter-fishermen in Norway and Scotland

3. J.C. Stone (1971) A locational guide to the Pont, Gordon, and Blaeu maps of Scotland

4. R. Wright and W. Ritchie (1975) The survey and photo-interpretation of the Sands of Forvie, Aberdeenshire

5. C.L. Dixon (1977) The development of agricultural policy in Zambia, 1964-1971

6. A.S. Mather (1978) State aided land settlement in Scotland

7. J.C. Stone (1979) A guide to the administrative boundaries of northern Rhodesia

8. R.E.H. Mellor (1979) German railways: a study in the historical geography of transport

9. A.S. Mather and R.J. Ardern (1981) An annotated bibliography of rural land use in the highlands and islands of Scotland

10. D. Omand and J. Porter (1981) The flagstone industry of Caithness

11. L.A. Ewan (1981) A palynological investigation of a peat deposit near Banchory: some local and regional environmental implications

12. J.H. Farrington, P.A. Stanley and S.M. Bain (1982) Public transport and accessibility in north west Sutherland

13. A.M. Armstrong and A.S. Mather (1983) Land ownership and land use in the Scottish Highlands

14. D.P. Willis (1983) Moorland and shore: their place in the human geography of old Orkney

15. J.N. Moore (1983) The mapping of Scotland: a guide to the literature of Scottish cartography prior to the Ordnance Survey

16. R.E.H. Mellor (1983) The Rhine: a study in the geography of water transport

17. J.R. Coull (1984) The evolution of settlement in the Buchan district of Aberdeenshire since the late sixteenth century: the evidence from cartographic sources and from the 1696 poll tax assessment

18. E.L. Naylor (1985) Socio-structural policy in French agriculture

19. R.E.H. Mellor (1987) National defence: the military aspects of political geography: a reconnaissance study

20. V.V. Ngo (1987) Cartobibliography of the Cameroon

21. G. Whittington and W. Ritchie (1988) Flandrian environmental evolution on north-east Benbecula and southern Grimsay, Outer Hebrides, Scotland

22. G. Whittington, K.J. Edwards and P.R. Cundill (1990) Palaeoenvironmental investigations at Black Loch, in the Ochil Hills of Fife, Scotland

23. W. Ritchie and S. Penland (1990) Coastline erosion and washover penetration along the Bayou Lafourche barrier shoreline between 1978 and 1985 with special reference to hurricane impacts

24. J.N. Moore (1991) The historical cartography of Scotland: a guide to the literature of Scottish maps and mapping prior to the Ordnance Survey

25. A.S. Mather (1993) The effect of nature-conservation designations on land use in northern Scotland

26. R.E.H. Mellor (1994) Railways in Britain: an historical-geographical perspective

27. J.A. McMullen, K.E. Barber and B.J. Johnson (2000) Contributions of palaeoecology to the conservation management of raised bogs in the United Kingdom 
28. I.B.M. Ralston and K.A. Sabine with S.J. Boardman, K.J. Edwards, A.M.D. Gemmell, M.K. Greig, J.I. McKinley and P.A. Sabine (2000) Excavations of second and first millennia BC remains on the Sands of Forvie, Slains, Aberdeenshire 
Appendix 6: Syllabus of MA Degree Examinations GEOGRAPAHY, academic session 1971-72

\section{Syllabus of MA Degree Examinations GEOGRAPHY}

Prescribed work for June and September 1971

\section{ORDINARY DEGREE}

(1) The subjects of the class lectures

(2) Prescribed readings: Candidates will be required to read prescribed parts of the following among other works: R.J. Harrison Church et al An Advanced Geography of Northern and Western Europe (Hulton); A.N. Strahler An Introduction to Physical Geography (Wiley); A.V. Perpillon Human Geography (Longmans); R.E.H. Mellor Comecon (Van Nostrad). All students must have an Atlas with relief and other physical maps such as Phillips University Atlas.

\section{ADVANCED DEGREE}

(1) The subjects of the class lectures

(2) Prescribed readings: Candidates will be required to read prescribed parts of the following among other works: A.T. Grove Africa South of the Sahara (Oxford University Press); or A.B. Mountjoy and C. Embleton Africa, a Geographical Study (Hutchinson); S.R. Eyre Vegetation and Soils -a world outline (Edward Arnold) or W.D. Billings Plants and the Ecosystem (MacMillan); J.W. Watson North America (Longman); R.C. Ward Hydrology (McGraw-Hill); R.G. Barry and R.J. Chorley Atmosphere, Weather and Climate (Methuen).

(Source: The Aberdeen University Calendar for 1970-71, pp. 76-77

The Honours examination in Geography comprises seven papers, a thesis, and an assessment of practical work completed in class:

(1) Systematic Geography I

(2) Systematic Geography II

(3) Systematic Geography III

(4) General Geography

(5) Regional Geography

(6) Special Subject I

(7) Special Subject II

Source: Aberdeen University Calendar for 1971-72, pp. 76-77 
Appendix 7: A selection of distinctions accorded to members of the Department of Geography and Environment while in employment or close association with the Department

Fellowship of the Royal Society of Edinburgh (FRSE)

Andrew O'Dell, 1951

Ken Walton, 1970

Bill Ritchie, 1982

Chalmers Clapperton, 1992

Roger Crofts, $2001^{1}$

Kevin Edwards, 2002

Doerthe Tetzlaff, 2017

Membership of the Academia Europaea (MAE)

Kevin Edwards, 2012

Honorary Doctorates

Mike Woods Hon DSc (Oxford Brookes), 1997

William Ritchie Hon DUniv (Stirling), 2003

Roger Crofts Hon DSc (St Andrews) 2004, Glasgow (2013)

\section{Higher Doctorates}

Chris Soulsby DSc (Aberdeen), 2005: 'Hydrological pathways, biogeochemical interactions and ecological responses in catchment systems: towards a scientific basis for sustainable management'

Doerthe Tetzlaff DSc (Aberdeen), 2013: 'Tracing connections between landscapes and riverscapes - conceptualizing the links between catchment hydrology and in-stream ecology' Kevin Edwards DSc (St Andrews), 2014: 'Studies in Quaternary, Geographical and Archaeological Science'

UK Honours System Awards ${ }^{2}$

William Ritchie OBE, 1994, for services to higher education

Mike Woods OBE, 2002, for services to cartography

Brian Clark MBE, 2004, for services to the environment

Professor Roger Crofts CBE, 1998, for services to environmental management

Research Medal of the Royal Scottish Geographical Society

Chalmers Clapperton, 1999

Kevin Edwards, 2018

Mungo Park Medal for Exploration of the Royal Scottish Geographical Society

David Sugden 1993

Chalmers M Clapperton, 1997

Bartholomew Globe for Geographical Information of the Royal Scottish Geographical Society Jeffrey Stone, 2004

President's Award for Wider Society of the Royal Scottish Geographical Society Chalmers Clapperton, 1990 
Chris Soulsby, 2003

Honorary Fellowship of the Royal Scottish Geographical Society

Sandy Mather, 1994

Michael Wood, 1997

Jeffrey Stone, 2000

Roger Crofts, 2001

Tim Mighall, 2016

Lorna Philip, 2016

Kevin Edwards, 2018

Notes

1. Honorary Professor in Geography 1997-2007. Crofts held research positions in the department during the 1970s.

2. The year of notification in the London Gazette is indicated. 
i In 1641, King Charles I had sanctioned the unification of both institutions 'in one university', to be called 'King Charles's University of Aberdeen' or the 'Caroline University' (Carter and McLaren 1994, p. 32); in 1654, Oliver Cromwell (Lord Protector under the Commonwealth republic) referred to King's and Marischal as 'the Colleges of Old and New Aberdeen' of 'the University of Aberdeen' (ibid. p. 40). The two constituent colleges reverted to independent university status following the Restoration of 1660, under King Charles II (NSA 1845).

ii The MA is an earned undergraduate degree in the ancient Scottish universities, generally of 4 years duration for Honours and equivalent to the BSc. It should not be confused with postgraduate taught or research Masters degrees, nor with the 'unearned', unexamined MAs conferred on BA graduates or staff members of the Universities of Oxford, Cambridge and Dublin.

iii St Andrews (founded 1413), Glasgow (1451), King's College, Aberdeen (1495), Edinburgh (1582), Marischal College (1593) - there was also the short-lived University of Fraserburgh (Royal Charter 1592, Principal appointed 1597, closed after Principal's arrest, ca 1607).

iv The original source of this information reported in Wood (1993) is the Clerk of Penicuik papers held in the National Records of Scotland, SRO GD 18/5036/5, 9, 10, 18.

${ }^{v}$ A Geology department at the University of Aberdeen was formally established in 1908. Alfred William Gibb was appointed Assistant Lecturer in Geology in 1895 and promoted to a full lectureship in 1900. He was appointed to the newly created Kilgour Chair in Geology in 1922, a post he held until his retirement in 1936.

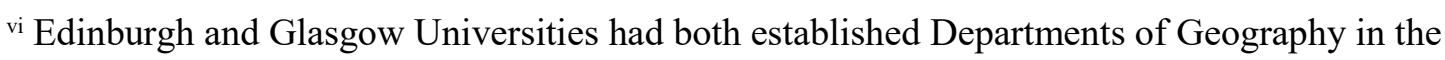
first decade of the twentieth century, in 1908 and 1909 respectively (see Withers (2008) and Lorimer and Philo (2009) for centenary reflections on the Edinburgh and Glasgow departments). The departments in St Andrews and Dundee came later, in 1935 (see Findlay and Werritty, 2010, for a review of the Dundee department's $75^{\text {th }}$ anniversary); at this stage, Dundee (as University College) was a constituent college of the University of St Andrews.

${ }^{\text {vii }}$ McFarlane's Economic Geography ran to five editions, the fifth being published in 1949, four years after his retirement. The fourth and fifth editions were co-authored with Oxford University geographer CFWR (Rowley) Gullick. 
viii Examination papers for Geography from session 1924-25 onwards are available to consult in the University of Aberdeen library, with papers catalogued as L Aa P72 Exa.

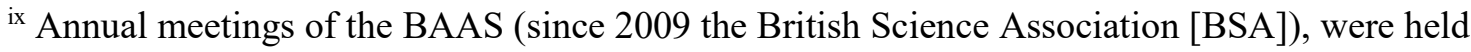
from 1831 onwards and were the precursors to the conferences and learned society meetings that punctuate the academic year today. Although dominated by academics, they were, and are, open to all.

${ }^{\mathrm{x}}$ Winifred Day was the first female member of academic staff in Geography at Aberdeen University. Following her departure in 1951 there was a gap of 26 years before another woman, Judith Maizels, was appointed to an academic position in the department. In the 100 years of the Department only nine women have held core-funded academic positions, seven of whom were appointed in the last 25 years.

${ }^{x i}$ Son of the well-known novelist John Buchan, Johnnie Buchan, the second Baron Tweedsmuir, served as Rector of Aberdeen University from 1948-51. A colonial administrator and naturalist (he and his wife jointly created the Protection of Birds Act, 1954), he actively supported the scientific expedition to Libya in 1951 and the later work conducted on St Ninian's Isle, Shetland, under the direction of Andrew O'Dell.

xii Other publications arose from the expedition, $c f$ Gimingham (1955), Gimingham \& Walton (1954).

xiii For further details see O'Dell 1959a,b,c and d. Images and other information about the St Ninian's Isle treasure are available at https://www.nms.ac.uk/explore-ourcollections/stories/scottish-history-and-archaeology/st-ninians-isle-treasure/.

${ }^{\text {xiv }}$ Upon its return to Shetland in 2013, two Aberdeen geographers, Kevin Edwards and Ed Schofield, were national delegates of the $16^{\text {th }}$ Viking Congress.

xv Under the 1966 Education (Scotland) Act the number of Universities in Scotland doubled from four to eight.

xvi The articles in The Orb could be a product of an exercise undertaken by undergraduate students in class. Student data are compiled and accompanied by a choropleth map, the type of mapping exercise many readers of this paper would have been required to undertake during undergraduate studies. The authors of the two articles used to prepare this text were James A. T. Young (1961) and Richard Ardern (1968).

xvii Lorna Philip's mother was a student at Aberdeen University in the early 1960s. Domiciled in Elgin, her 1960-61 grant received from Morayshire was approximately half that she received the following year from the Scottish Education Department.

xviii The MSc RRRP was an interdisciplinary degree, led by Geography and involving staff from the Departments of Agriculture, Botany, Engineering, Political Economy, Forestry, Geology, Sociology, Social Science and Zoology. 
xix The Orb lists the following support staff in 1972-73: Charles Wilson, technical supervisor; Thomas Cook, deputy technical supervisor and map control; William Ross, engineering workshop; William Christie, instrument store; Gordon Murray, technician and woodworker; Bruce McKenzie, engineering technician; James Livingstone, photography, underwater diving; Derek Robertson, photography, underwater diving; Walter Bragg, map control; Valerie Bennett, laboratory technician; Bert Bremner, cartography; Alison Watt, cartography; Doris Cowie, photo-interpretation technician.

${ }^{x x}$ See https://www.scottish-places.info/features/featurefirst5125.html for further information

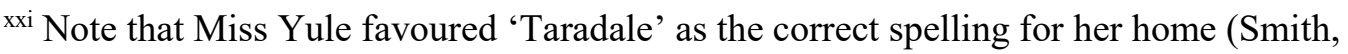
undated). The accepted contemporary spelling is Tarradale'.

xxii Eric Grant (MA 1963-67) who had previously been a Senior Lecturer in Geography at Middlesex University following completion of a Diploma in Archaeology at Cambridge University and a PhD in Geography at the University of Birmingham.

xxiii Twenty-eight O’Dell Memorial Monographs were published, the first in 1968, the last in 2000. A full list is presented in Appendix 5. Copies of all but 2 (numbers 20 and 28) are available in the University of Aberdeen's Sir Duncan Rice Library.

xxiv See contribution in this Special Issue by Chapman and Gemmell.

${ }^{x x v}$ Others may describe this stability as veering towards stagnation. Regular injections of 'new blood' would have benefited the Department in the 1970s and 1980s, helping to create a more balanced age profile amongst the staff and supporting a more vibrant research culture.

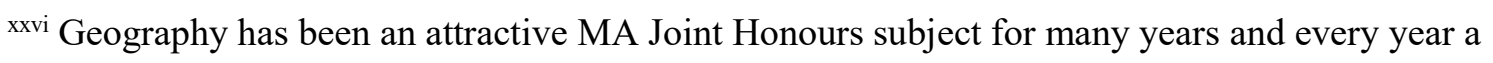
minority of Joint Honours students elect to complete a dissertation in their other subject. The dissertation lists held in Map Control are thus not a record of the number of students in each cohort but are the best proxy available for the 1990s and 2000s.

xxvii $\sim £ 2$ million in today’s terms; www.measuringworth.com/calculators/ppoweruk/ xxviii AHRC - Arts and Humanities Research Council; ESRC - Economic and Social Research Council; MRC - Medical Research Council.

${ }^{x x i x}$ A partnership between the Universities of Aberdeen, Abertay Dundee, Dundee, Edinburgh, Glasgow, Highlands \& Islands (through SAMS [Scottish Association for Marine Science]), St Andrews, Stirling and West of Scotland, the British Geological Survey and SUERC, the Scottish Universities Environmental Research Centre (East Kilbride). The Aberdeen lead for phase 1 was Kevin Edwards and that for phase 2 is Brice Rea.

${ }^{x x x}$ Phase 1 themes: Landscape dynamics; Terrestrial carbon cycle; Oceans, atmosphere and climate; Centre for earth system dynamics; Knowledge transfer links with society. Phase 2 themes: Landscape form, use and change; Carbon and biogeochemical cycles; 
Atmosphere. Oceans and climate; Centre for earth system dynamics; Transformation in society and environment policy. The SAGES Graduate School has provided a

comprehensive and supportive environment for doctoral students and its annual retreat is a popular highlight together with additional networking, training and mentoring events.

xxxi https://www.thecompleteuniversityguide.co.uk/leaguetables/rankings?s=Geography+\%26+Environmental+Science 